\title{
Scorpions from Ennedi, Kapka and Tibesti, the mountains of Chad, with descriptions of nine new species (Scorpiones: Buthidae, Scorpionidae)
}

\section{Скорпионы из Эннеди, Капка и Тибести, гор Чада, с описанием девяти новых видов (Scorpiones: Buthidae, Scorpionidae)}

\author{
Wilson R. Lourenço ${ }^{1}$, Bernard Duhem ${ }^{2}$ \\ \& John L. Cloudsley-Thompson ${ }^{3}$ \\ Вимьсон Р. Аоуренсо ${ }^{1}$ Бернар Аюэм², Ажкон $\Lambda$. КАаудсли-Томпсон ${ }^{3}$
}

\begin{abstract}
${ }^{1}$ Muséum national d'Histoire naturelle, Département Systématique et Evolution, UMR7205, CP 053, 57 rue Cuvier 75005 Paris, France. E-mail: arachne@mnhn.fr

${ }^{2}$ Muséum national d'Histoire naturelle, Direction des Collections, CP 039, 57 rue Cuvier 75005 Paris, France. E-mail: duhem@mnhn.fr ${ }^{3} 44$ Alconbury Road, Hackney, London E5 8RH, United Kingdom
\end{abstract}

KEY WORDS: Scorpion, Buthidae, Scorpionidae, new species, Sahara, Chad, Ennedi, Kapka, Tibesti, biogeography.

КЛЮЧЕВЫЕ СЛОВА: Скорпион, Buthidae, Scorpionidae, новый вид, Сахара, Чад, Эннеди, Капка, Тибести, биогеография.

ABSTRACT. Treating a collection of scorpions from the Ennedi, Kapka and Tibesti mountain massifs in Chad reveals an interesting fauna with several elements possibly endemic to these areas. Nine new species are described: Androctonus pallidus sp.n., Buthacus golovatchi sp.n., Butheoloides (s.str.) granulatus sp.n., Buthus hassanini sp.n., Compsobuthus boucheti sp.n., Hottentotta mateui sp.n., Orthochirus minor sp.n., Orthochirus tibesti sp.n. (Buthidae) and Scorpio ennedi sp.n. (Scorpionidae). Biogeographic comments are also added on the scorpion faunas of other Saharan massifs.

РЕЗЮМЕ. Изучение коллекции скорпионов из горных массивов Эннеди, Капка и Тибести в Чаде выявляет интересную фауну с несколькими элементами, вероятно, эндемичными для данных территорий. Описаны девять новых видов: Androctonus pallidus sp.n., Buthacus golovatchi sp.n., Butheoloides (s.str.) granulatus sp.n., Buthus hassanini sp.n., Compsobuthus boucheti sp.n., Hottentotta mateui sp.n., Orthochirus minor sp.n., Orthochirus tibesti sp.n. (Buthidae) и Scorpio ennedi sp.n. (Scorpionidae). Даны биогеографические замечания по скорпионам фаун других горных массивов Сахары.

\section{Introduction}

As already discussed elsewhere, scorpion diversity is particularly high in deserts and arid formations [Polis, 1990; Lourenço \& Duhem, 2007; Qi \& Lourenço, 2007]. The scorpion fauna of North Africa, in particular the one specifically adapted to the Sahara Desert, has been the subject of intense studies, earlier synthesized by Vachon [1952]. Nevertheless, detailed inventory research and revisions have since led to an increasing number of new species and even new genera. These have been the subject of several publications [e.g. Lourenço, 1998, 1999a, b, 2001, 2002, 2003, 2005, 2006; Lourenço \& Duhem, 2007; Qi \& Lourenço, 2007; Lourenço et al., 2009; Lourenço \& Leguin, 2011]. Still many further species have been predicted to await discovery.

Although the core Saharan region, defined by Vachon [1952] as the 'central compartment', has been the focus of most of scorpionological studies, other regions also call the attention of experts. The periSaharan zone forms an almost complete ring around the most arid core region of the desert. In this zone, genera such as Butheoloides Hirst, 1925 can be observed [Lourenço, 2002, 2010b]. Some unique endemic groups such as Riftobuthus Lourenço, Duhem et CloudsleyThompson, 2010 have been described from arid zones in Kenya [Lourenço et al., 2010]. Equally remarkable is a disjunct distribution shown by the genus Microbuthus Kraepelin, 1898, with some species occurring in Mauritania and Morocco in the West and the others in Eritrea, Djibouti and Oman in the East [Lourenço \& Duhem, 2007; Lowe, 2010]. Finally, several additional species are present only in refuge zones. These may be represented by oases, but in most cases correspond to the Saharan massifs such as Hoggar, Tassili N'Ajjer, Aïr, Adrar, Tibesti, Ennedi and Kapka. These areas have attracted the attention of naturalists 
since the middle of the $20^{\text {th }}$ century, and a number of works on scorpions have been published [Pellegrin, 1935; Vachon, 1940, 1950, 1958]. These preliminary results, however, proved to be unsatisfactory since most local elements in these massifs were simply associated with species known from other areas. More recent studies demonstrate that many of these local populations actually represent endemic species [Lourenço, 1999b, 2001, 2002, 2010a].

The present paper puts on record the results of studying a small collection of scorpions from the Ennedi, Massif du Kapka and Tibesti in Chad. These are the first true results for these particular refuge areas in Chad. Nine new species belonging to the families Buthidae and Scorpionidae are described.

\section{Ennedi, Massif du Kapka and Tibesti}

This ecoregion is located in the Sahelian regional transition zone where high mountains rise from lowlying semi-desert habitats. The height of these mountains creates an environment different from that of the surrounding areas; here water is not scarce and sand does not dominate the soil. This isolated rugged habitat supports endemic plant and small animal species, and provides a critical habitat for some vertebrate populations.

The largest portion of the East Saharan Montane Xeric Woodland ecoregion is located in Chad. It encompasses the Massifs of Tibesti, Ennedi and Kapka at an elevation over 1,400 m [Gillet, 1959]. A smaller outlier of this ecoregion is located in Sudan. Jebel Marra reaches heights exceeding 3,000 m. This ecoregion, comprised of three isolated areas, supports dry woodland vegetation surrounded by Sahel Acacia wooded grassland and deciduous bushland [White, 1983]. Happold [1969] found that the high jebels, which support areas of moisture-dependent habitat instead of desert and semi-desert, are of a higher biodiversity value.

Throughout this ecoregion, most of the year's rainfall occurs between May and September. Precipitation varies greatly with elevation, ranging from $150 \mathrm{~mm}$ to 500 $\mathrm{mm}$ in most areas, but reaching more than $1,000 \mathrm{~mm}$ in the higher parts of Jebel Marra.

Jebel Marra is volcanic in origin, with a relict crater now containing two lakes. Bare rock outcrops are found in many areas, although lithosols and yermosols also occur. While Jebel Marra is comprised of Tertiary basalts, the upland Ennedi Plateau, above 1,800 $\mathrm{m}$ to $2,000 \mathrm{~m}$, differs geologically in having a cap of Devonian sandstone [White, 1983]. Due to its huge size, Jebel Marra offers multiple habitat types; valleys with deep litter soil and wooded forest, bare rocky outcrops, tall-grass savanna, and a high elevated plateau of volcanic ash with short grasses and wind-blown bushes [Happold, 1969].

In terms of the phytogeograhical classification of White [1983], this area is part of the Sahelian regional transition zone which ranges between 1,800 and 2,000 $\mathrm{m}$. The actual vegetation of the ecoregion is mapped as Sahelomontane [White 1983], one of three such areas in northern Africa. The flora shows affinities to that of North Africa, the Ethiopian Highlands, the Kenyan Mountains, and Europe [Wickens, 1976]. The areas of higher elevation, however, seem to have been dominated by Olea laperrinei scrub forest. The current vegetation is dominated by secondary grassland, with $O$. laperrine $i$ scattered across the landscape [Gillet, 1959; CloudsleyThompson, 1966, 1967; White, 1983].

In terms of plants, a good number of species endemic to the Sahel region occurs in this ecoregion [White, 1983]. The ecoregion, particularly the Ennedi Plateau, is also an important location for some vertebrates. The ecoregion also includes some elements of Afrotropical and Palearctic faunas. The only habitats probably remaining undisturbed are on deep valley floors.

The Tibesti Mountains consist of a range of largely inactive volcanoes located at the northern edge of the Chad Basin in the Borkou and Tibesti regions of northern Chad. The massif is one of the most prominent features of the central Sahara Desert and covers an area of approximately $100,000 \mathrm{~km}^{2}$. Its northern slopes extend into southern Libya. It is one of the most isolated arid areas on Earth. The mountains are the largest and highest in the central Sahara. Most are inactive volcanoes, but four could potentially be active.

The highest peak in the mountains is Emi Koussi, $3,415 \mathrm{~m}$. Other summits include Kegueur Terbi (3,376 $\mathrm{m})$, Tarso Taro $(3,325 \mathrm{~m})$, the potentially active volcano Tarso Tousside $(3,265 \mathrm{~m})$ and Tarso Voon $(3100 \mathrm{~m})$. The peak Bikku Bitti, located in the northern area, is the highest mountain in Libya [Gourgaud \& Vincent, 2004]. While the high peaks themselves are all composed of volcanic material, the mountains stand on a broad uplifted area caused by a mantle plume. Active volcanism began as early as the Oligocene, although the major features that mark its surface date from the Lower Miocene to Quaternary period, representing a key example of continental hot spot volcanism. The basement of the mountains is Precambrian Schist, overlaid by Palaeozoic Sandstone, all capped by Tertiary and Pleistocene outpourings of basalt.

The range has a substantially wetter climate than that of the surrounding desert. The run-off of precipitation is more regular in the mountains than the lowland desert. The rainfall during the 1950 s was considerable, although still probably within $600 \mathrm{~mm} / \mathrm{m}^{2}$ per year. Since 2000, rainfall has been less than $60 \mathrm{~mm} / \mathrm{m}^{2}$. The mean maximum temperature is approximately $30^{\circ} \mathrm{C}$ in the lowlands and decreases to $20^{\circ} \mathrm{C}$ at the highest elevations. The mean minimum temperatures are $12^{\circ} \mathrm{C}$ in the lowlands, but decrease to $9^{\circ} \mathrm{C}$ over most of the ecoregion and are as low as $0^{\circ} \mathrm{C}$ at the highest elevations during winter.

Due to the aridity of the Sahara, the Tibesti massif is nearly free from accumulated vegetal soil, and robust plant life is largely absent from almost everywhere throughout the year. The Tibesti Mountains lie in the 
ecological region known as the Tibesti-Djebel Uweinat Montane Xeric Woodlands. In these mountains, there is only one lake, the Mare de Zoui, along with a number of oases. The Tibesti mountain vegetation varies according to the elevation and slope. Large areas of Enneri radiate from the southwestern slopes and support tree species such as the Doum Palm (Hyphaene thebaica), Salvadora persica, Tamarix articulata, Acacia albida, and other tropical shrubs of the genera Abutilon, Hibiscus and Tephrosia [White, 1983]. The Saharamontane vegetation of the higher elevations supports the endemic Ficus teloukat, which grows on the southern and southwestern slopes, Myrtus nivellei on the western slopes, and Tamarix gallica nilotica on the wetter northern slopes. Remnant tropical and Mediterranean plant species are seen throughout this ecoregion, including palms, Hibiscus sp. and Rhynchosia sp. [White, 1983].

\section{Synopsis of the known scorpion faunas from the Sahara mountain ranges}

As emphasized previously, the Sahara mountain ranges have attracted the attention of naturalists since the middle of the $20^{\text {th }}$ century. Some observations on scorpions appeared [Pellegrin, 1935; Vachon, 1940, 1950, 1958]. These early publications, however, were far from satisfactory because the majority of the authors simply associated local species with other, already known forms from other areas of the Sahara. Only more recently have new studies begun to demonstrate that many of these local populations actually represent endemic species [Lourenço, 1999b, 2001, 2002, 2010a].

\section{Adrar}

This region in Mauritania has proved to be one of the most interesting biogeographically, with endemic elements described since the onset of early studies. The most important are Buthacus occidentalis Vachon, 1953, Compsobuthus berlandi Vachon, 1950, Lissothus occidentalis Vachon, 1950 and Microbuthus fagei Vachon, 1949 [Vachon, 1953]. More recently, further endemic elements have been described from this area. These include Androctonus aleksandrplotkini Lourenço et Qi, 2007, Mauritanobuthus geniezi Qi et Lourenço, 2006, and Orthochirus atarensis Lourenço et Leguin, 2011 [Lourenço \& Qi, 2007; Qi \& Lourenço, 2006; Lourenço \& Leguin, 2011].

\section{Hoggar and Tassili N'Ajjer}

Vachon [1958], in his review of the scorpion faunas of these mountain areas, listed 10 species, some of which are undoubtedly endemic such as Androctonus hoggarensis (Pallary, 1929), Buthacus foleyi Vachon, 1948, and Cicileus exilis (Pallary, 1928). More recently, other endemic elements have been described such as Pseudolissothus pusillus Lourenço, 2001, Buthus tassili Lourenço, 2002, Compsobuthus tassili Lourenço, 2010 and Orthochirus tassili Lourenço et Leguin, 2011
[Lourenço, 2001, 2002, 2010a; Lourenço \& Leguin, 2011].

Further studies on the scorpions of these mountain regions are being carried out (Lourenço, in preparation) and will probably reveal further new endemic species.

\section{Aïr}

This mountain region was studied superficially by Vachon [1950], with only four scorpion species reported. Two, Androctonus amoreuxi (Audouin, 1826) and Leiurus quinquestriatus (Ehrenberg, 1828), are commons elements in the Saharan region. The records of the other two species, Androctonus hoggarensis and Compsobuthus werneri (Birula, 1908), require confirmation. Only studying new material from this area can provide a better knowledge of its faunal composition.

\section{Tibesti, Ennedi and Kapka}

A literature survey shows that only a single short note has been published [Pellegrin, 1935] concerning the scorpions of Tibesti, with a sole species recorded: Leiurus quinquestriatus. In a more recent publication, Lourenço [2004] described Hottentotta acostai Lourenço, 2004, from the South of Tibesti.

No information about the scorpion faunas of both the Ennedi and Kapta mountains seems to have ever been published. Only informal references have indicated the presence of Leiurus quinquestriatus in these regions. The new species described here have been collected during field trips carried out by a team of the Muséum national d'Histoire naturelle, Paris in 1958 in the Ennedi and by our late colleague P.-M. Brignoli in the late 1970s and early 1980s in Tibesti and Kapta.

\section{Material and methods}

All type material is deposited in the collections of the Muséum national d'Histoire naturelle, Paris, France (MNHN). Illustrations and measurements of scorpions were made with the aid of a Wild M5 stereo-microscope with a drawing tube (camera lucida) and an ocular micrometer. Measurements follow Stahnke [1970] and are given in $\mathrm{mm}$. Line drawings and photographs are not executed to scale. Trichobothrial notations are those of Vachon [1974] and morphological terminology mostly follows Vachon [1952] and Hjelle [1990].

\section{Taxonomic part}

Buthidae C.L. Koch, 1837

Androctonus Ehrenberg, 1828

Androctonus pallidus sp.n. Figs 1-11.

HOLOTYPE O', Chad, Massif du Kapka, VI.1981, leg. P.M. Brignoli.

PARATYPES: $2 \sigma^{\top} \sigma^{7}$, same locality, together with holotype. 


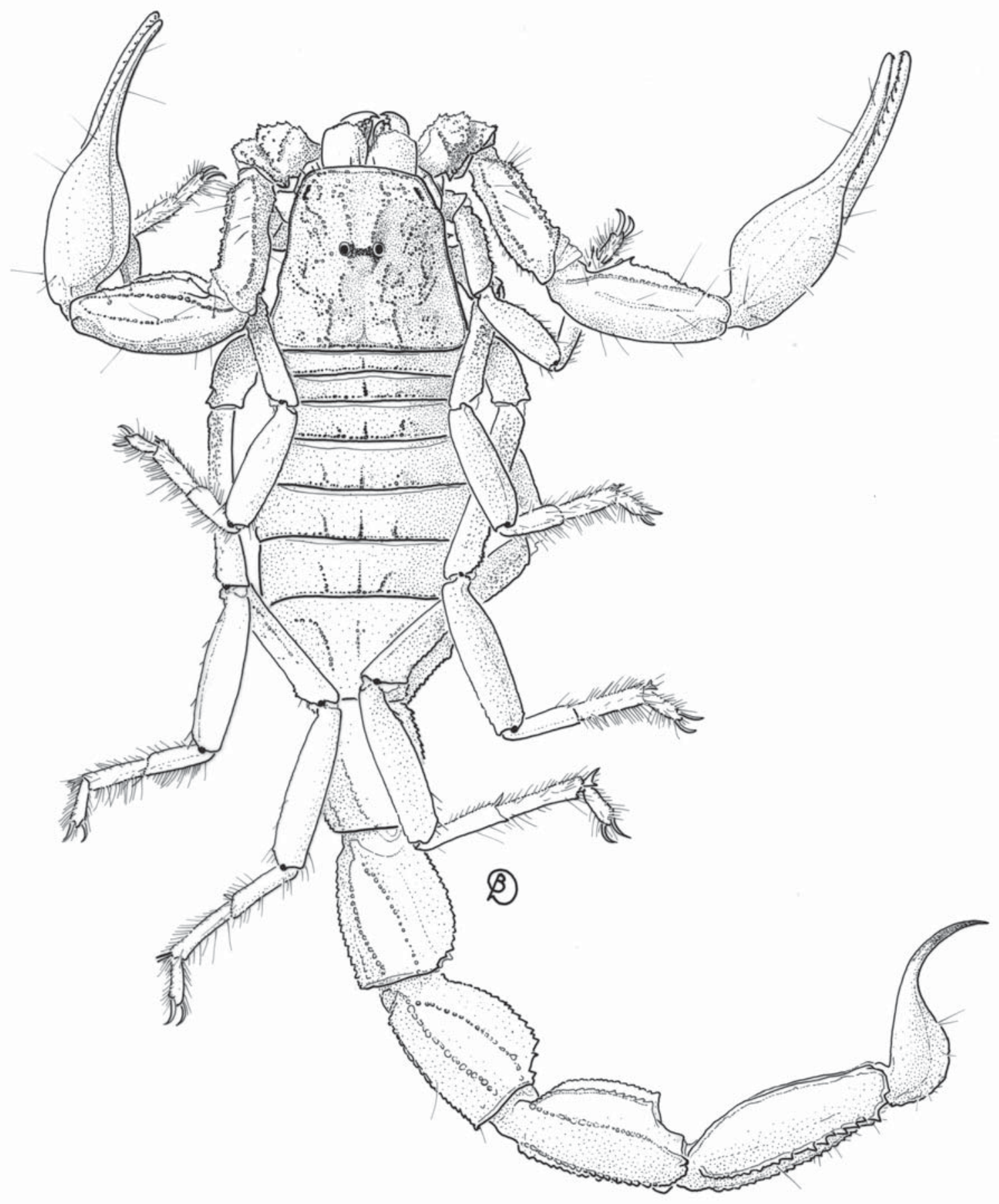

Fig. 1. Androctonus pallidus sp.n., holotype, habitus.

Рис. 1. Androctonus pallidus sp.n., голотип, габитус. Нарисовано без масштаба. 

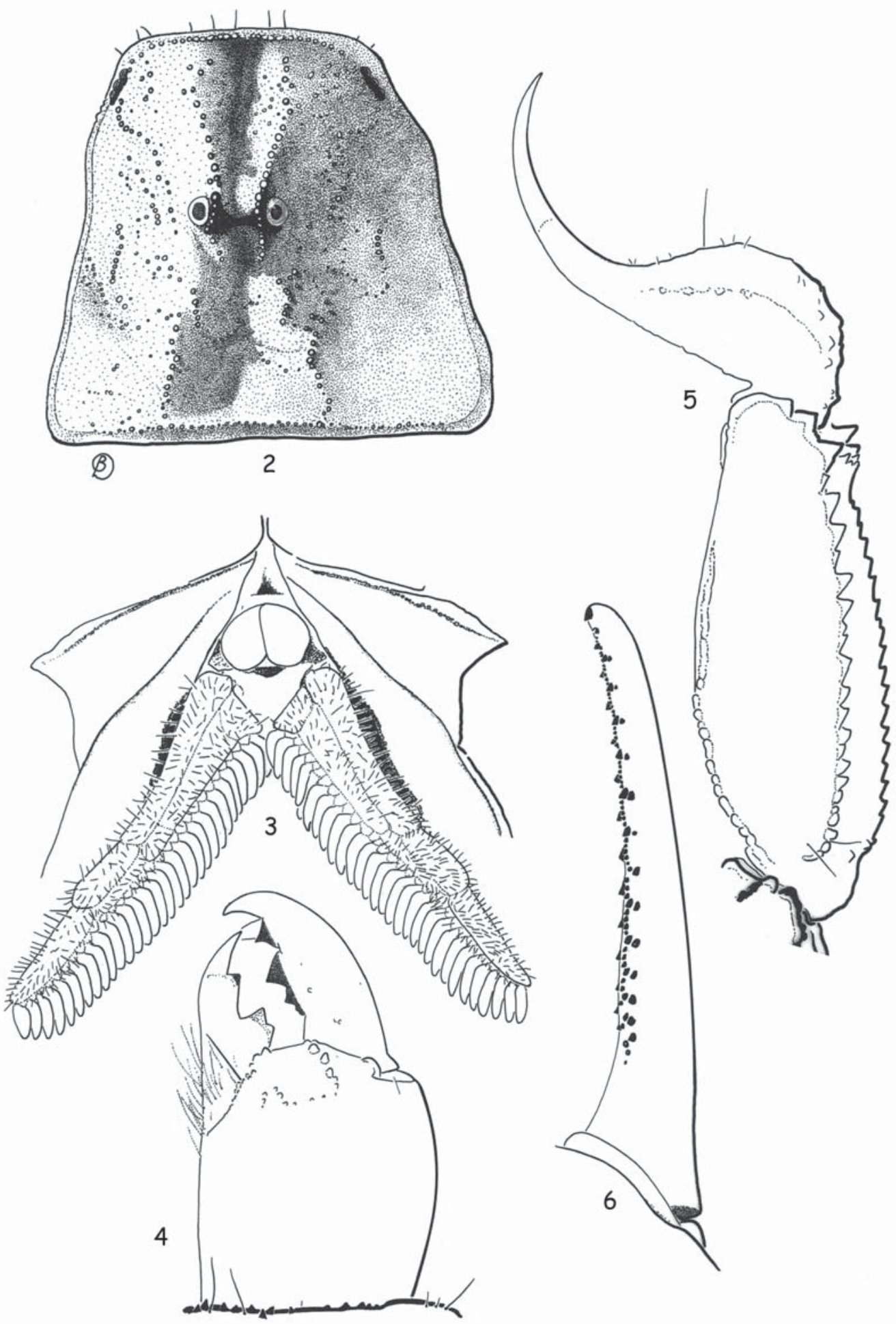

Figs 2-6. Androctonus pallidus sp.n., holotype: 2 - carapace, dorsal aspect; 3 - coxapophysis, sternum, genital operculum and pectines; 4 - chelicera, dorsal aspect; $5-$ metasomal segment $V$ and telson, lateral aspect; 6 - cutting edge of movable finger with rows of granules.

Рис. 2-6. Androctonus pallidus sp.n., голотип: 2 - карапакс, сверху; 3 - коксапофиз, стернит, крышечка гениталий и пектины; 4 - хелицера, сверху; 5 - сегмент V метасомы и тельсон, сбоку; 6 - режущий край подвижного пальца с рядами гранул. 


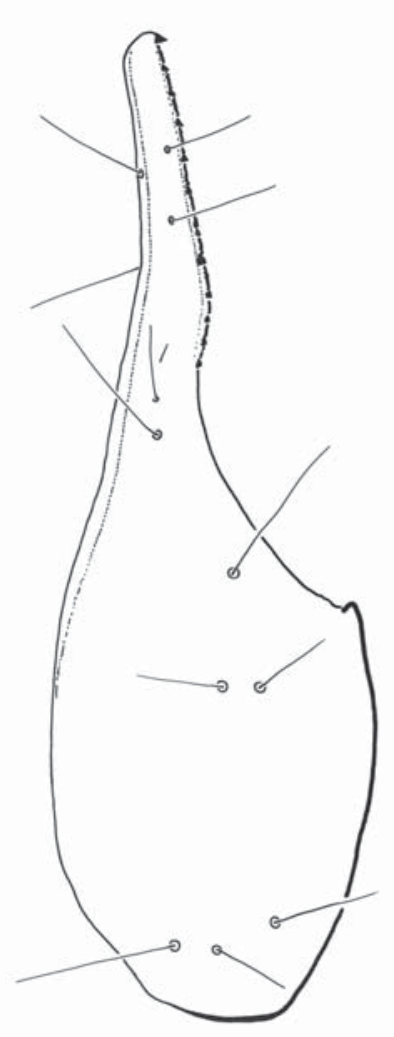

7
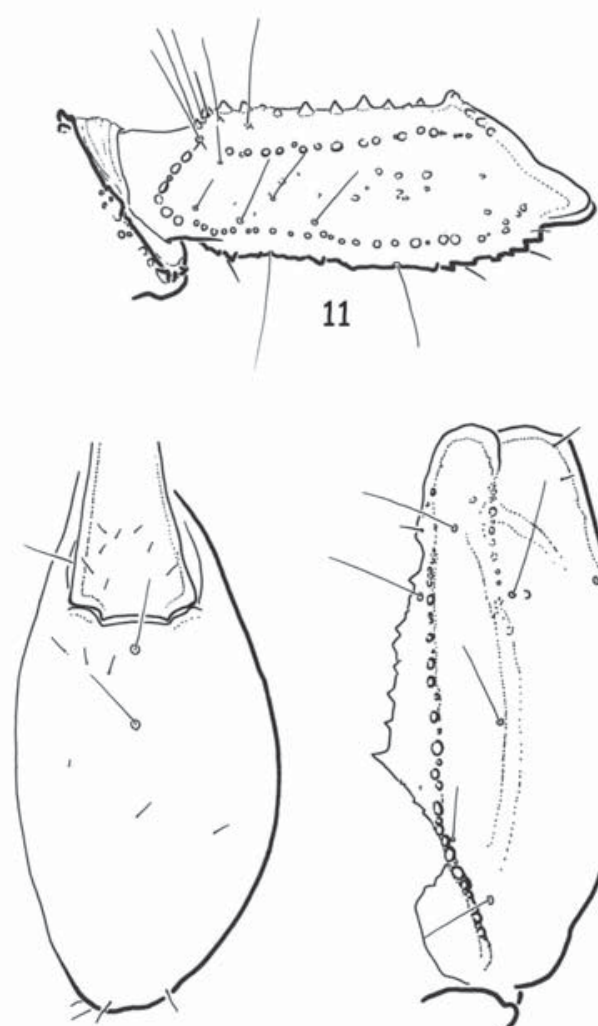

8

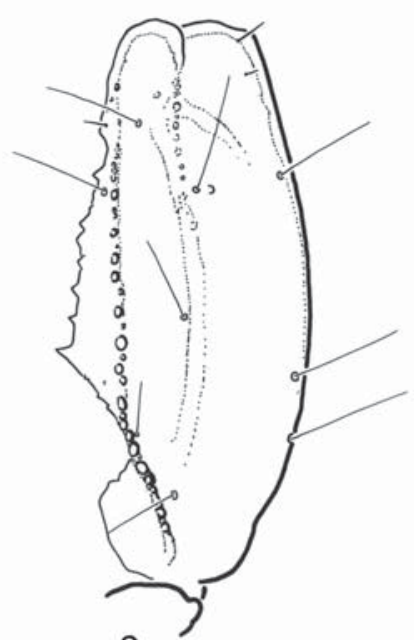

9

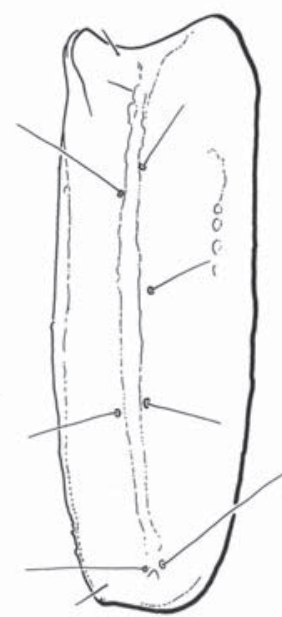

10

Figs 7-11. Androctonus pallidus sp.n., holotype, trichobothrial pattern: $7 \& 8$ - chela, dorso-external and ventral aspects, respectively; $9 \& 10$ - patella, dorsal and external aspects, respectively; 11 - femur, dorsal aspect.

Рис. 7-11. Androctonus pallidus sp.n., голотип, распределение трихоботрий: 7 и 8 - хела, соответственно снаружи и сверху и снизу; 9 и 10 - пателла, соответственно сверху и снизу; 11 - бедро, сверху.

NAME. The specific name refers to the pale coloration of the new species.

DIAGNOSIS. Scorpions of small to medium size in relation to the other congeners, reaching a total length of $60-65 \mathrm{~mm}$ in $\sigma^{7} \sigma^{7}$. General coloration yellowish to pale yellow. Carinae on carapace moderately to weakly developed. Metasomal segments I to $\mathrm{V}$ narrow and subequal in width; dorsal depression on segments I to IV shallow. Anal arc with three sharp lobes and a reduced fourth lobe. Fixed and movable fingers with 10 or 11 rows of granules. Pectines with 30 to 31 teeth in $\sigma^{7} \sigma^{\top}$.

RELATIONSHIPS. Androctonus pallidus sp.n. can be distinguished from the other congeners distributed in the central region of Sahara by the following characters: (i) an overall yellowish to pale yellow coloration, (ii) carinae on carapace and metasomal segments moderately to weakly marked, (iii) fingers of chela with 10 or 11 rows of granules, (iv) $\sigma^{7}$ chela without any scalloping of proximal dentate margin of fixed finger, (v) anal arc with three sharp lobes and one small latero-dorsal lobe.

DESCRIPTION. Coloration mainly yellowish to pale yellow. Prosoma: Carapace yellowish; eyes marked by dark pigment. Mesosoma yellowish. Metasoma: Segments
I to V yellowish; carinae slightly coloured with reddishyellow pigment; vesicle yellowish; aculeus reddish-yellow at its base and dark at its extremity. Venter yellowish; genital operculum and pectines pale yellow. Chelicerae yellowish without any variegated spots; fingers reddish-yellow with dark reddish teeth. Pedipalps yellowish; fingers with oblique rows of granules dark reddish. Legs pale yellow without any spots.

Carapace moderately to weakly granular; anterior margin slightly convex. Carinae moderately to weakly marked; anterior median moderately granular; central median and posterior median carinae weakly granular. All furrows moderate to weak. Median ocular tubercle somewhat anterior to centre of carapace. Eyes separated by almost 2.5 ocular diameters. Four pairs of lateral eyes: first three of moderate size, last ones only slightly reduced. Sternum triangular and narrow; longer than wide. Mesosoma tergites weakly granular. Three longitudinal carinae moderately to weakly crenulate in all tergites; lateral carinae vestigial in tergites I and II. Tergite VII pentacarinate. Venter: Genital operculum divided longitudinally, forming two oval plates. Pectines: Pectinal tooth count $31-31$ in $\sigma^{7}$ holotype (30-30 in paratypes); middle basal lamella of pectines 


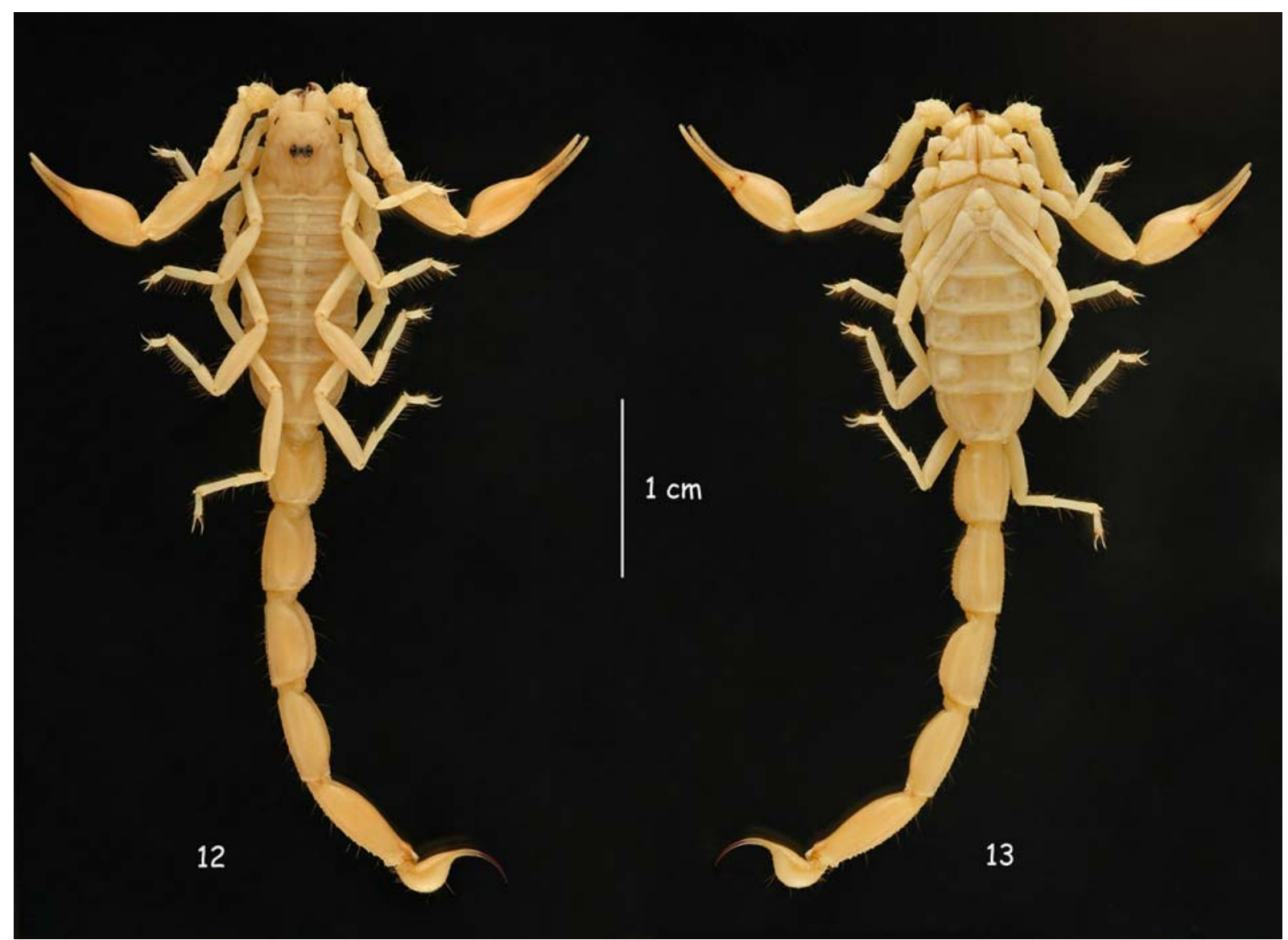

Figs 12 \& 13. Buthacus golovatchi sp.n., holotype, habitus, dorsal and ventral aspects, respectively.

Рис. 12-13. Buthacus golovatchi sp.n., голотип, габитус, соответственно сверху и снизу.

not dilated. Sternites without granules, smooth, with elongated spiracles; four weakly marked carinae on sternite VII; other sternites acarinate, with two vestigial furrows. Metasoma: Segment I with 10 carinae, moderately crenulated; segments II to IV each with 8 carinae, moderately crenulated; lateral inframedian carinae represented in segments II and III by 1-3 granules; all segments with a smooth shallow dorsal depression; segment $\mathrm{V}$ with five carinae; latero-ventral carinae crenulate with several spinoid denticles; ventral median carina not divided posteriorly; anal arc composed of 9 or 10 inconspicuous ventral teeth, three sharp lateral lobes and one small latero-dorsal lobe. Intercarinal spaces lustrous and smooth. Telson with some strong granulations on ventral surface; aculeus moderately curved and slightly longer than vesicle, devoid of a subaculear tooth. Cheliceral dentition as defined by Vachon [1963] for the family Buthidae; external distal and internal distal teeth subequal in length; basal teeth on movable finger small, but not fused; ventral aspect of both fingers and manus covered with long dense setae. Pedipalps: Femur pentacarinate; patella with eight carinae, but only dorso-internal and internal ones well marked; other carinae vestigial; chela with only vestigial carinae; all faces weakly granular to smooth. Fixed and movable fingers with 10 or 11 oblique rows of granules. Internal and external accessory granules present, strong; three accessory granules at distal end of movable finger next to terminal denticle. Legs with setation typical of a psammophilous species; tibial spur moderately marked on legs III and IV; pedal spurs moderately to strongly marked on legs I to IV. Trichobothriotaxy: Trichobothrial pattern of type A, orthobothriotaxic as defined by Vachon [1974]. Dorsal trichobothria of femur arranged in $\beta$ configuration [Vachon, 1975].

Morphometric values (in $\mathrm{mm}$ ) of holotype. Total length, $60.4\left(67.5^{*}\right)$. Carapace: length, 7.5; anterior width, 5.2; posterior width, 8.3. Mesosoma length, 14.5. Metasomal segments. I: length, 5.2; width, 4.7; V: length, 8.7; width, 4.3; depth, 3.5. Telson length, 7.1. Vesicle: width, 2.5; depth, 2.3. Pedipalp: femur length, 5.9, width, 2.2; patella length, 7.6, width, 3.1; chela length, 12.7, width, 3.6, depth, 3.9; movable finger length, 7.9. (* Including telson length).

\section{Buthacus Birula, 1908}

\section{Buthacus golovatchi sp.n.}

Figs 12-23.

HOLOTYPE ơ, Chad, Massif du Kapka, 720 m, VI.1981, leg. P.M. Brignoli. 


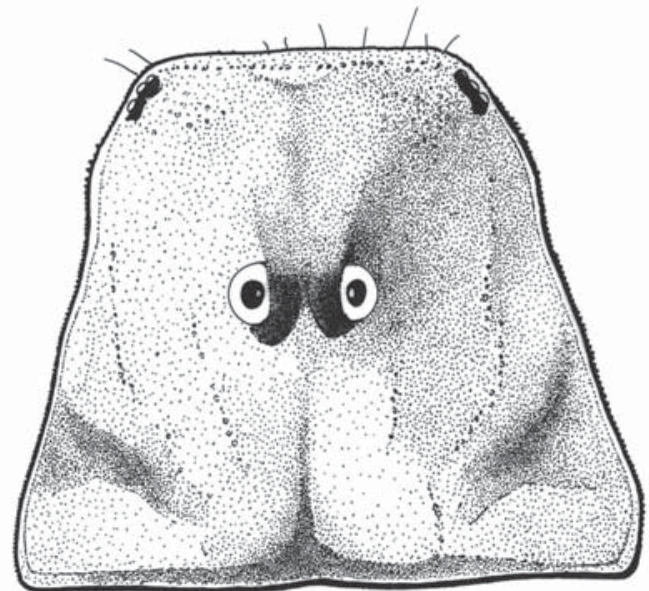

14
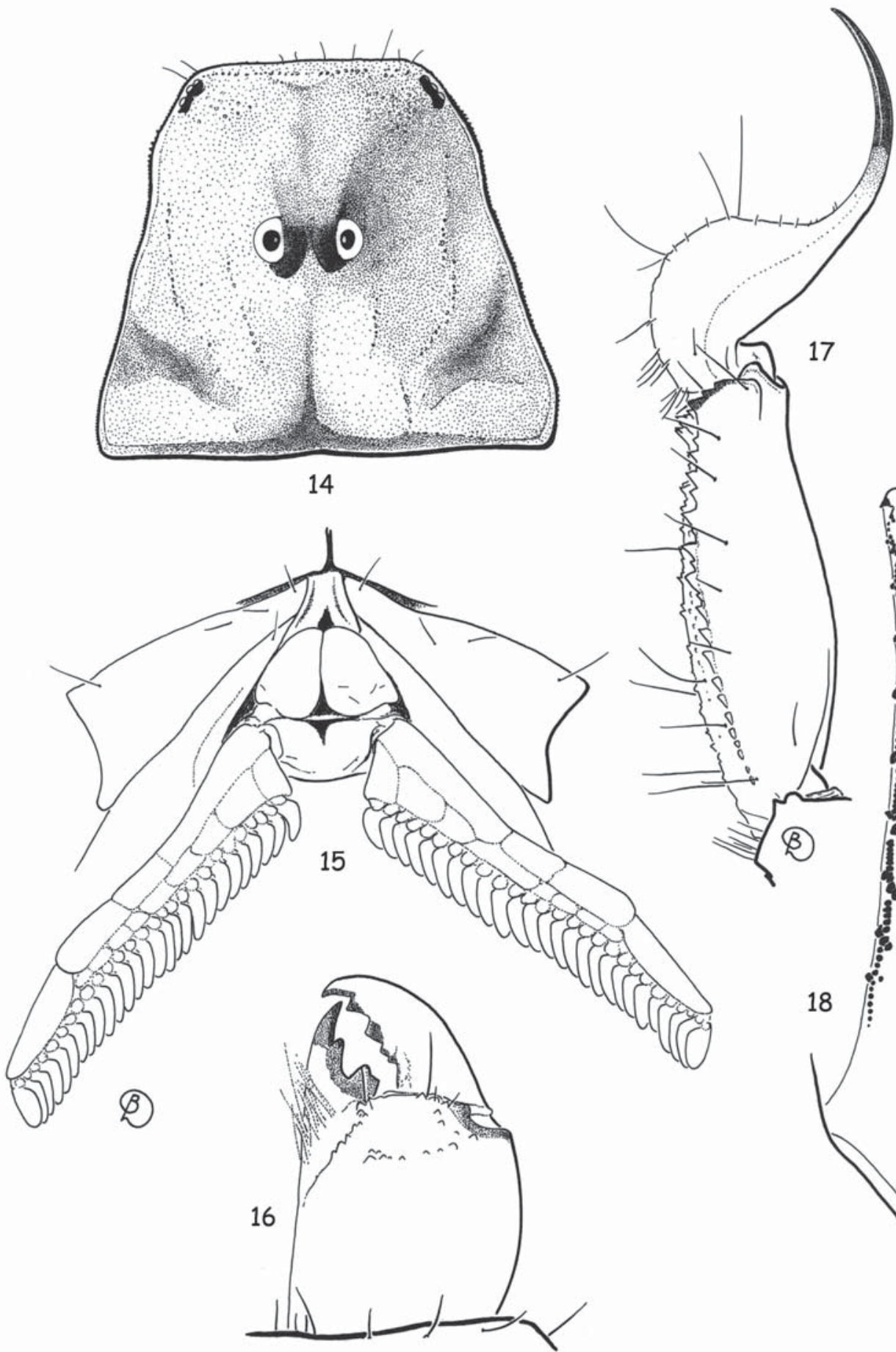

17
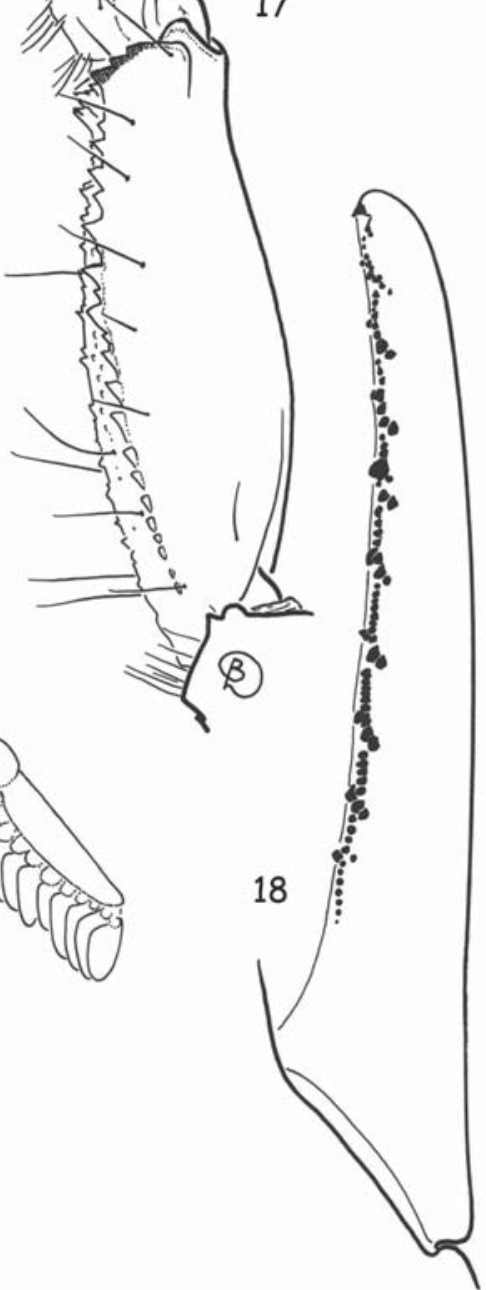

Figs 14-18. Buthacus golovatchi sp.n., holotype: 14 - carapace, dorsal aspect; 15 - coxapophysis, sternum, genital operculum and pectines; 16 - chelicera, dorsal aspect; 17 - metasomal segment $\mathrm{V}$ and telson, lateral aspect; 18 - cutting edge of movable finger with rows of granules.

Рис. 14-18. Buthacus golovatchi sp.n., голотип: 14 - карапакс, сверху; 15 - коксапофиз, стернит, крышечка гениталий и пектины; 16 - хелицера, сверху; 17 - сегмент V метасомы и тельсон, сбоку; 18 - режущий край подвижного пальца с рядами гранул. 


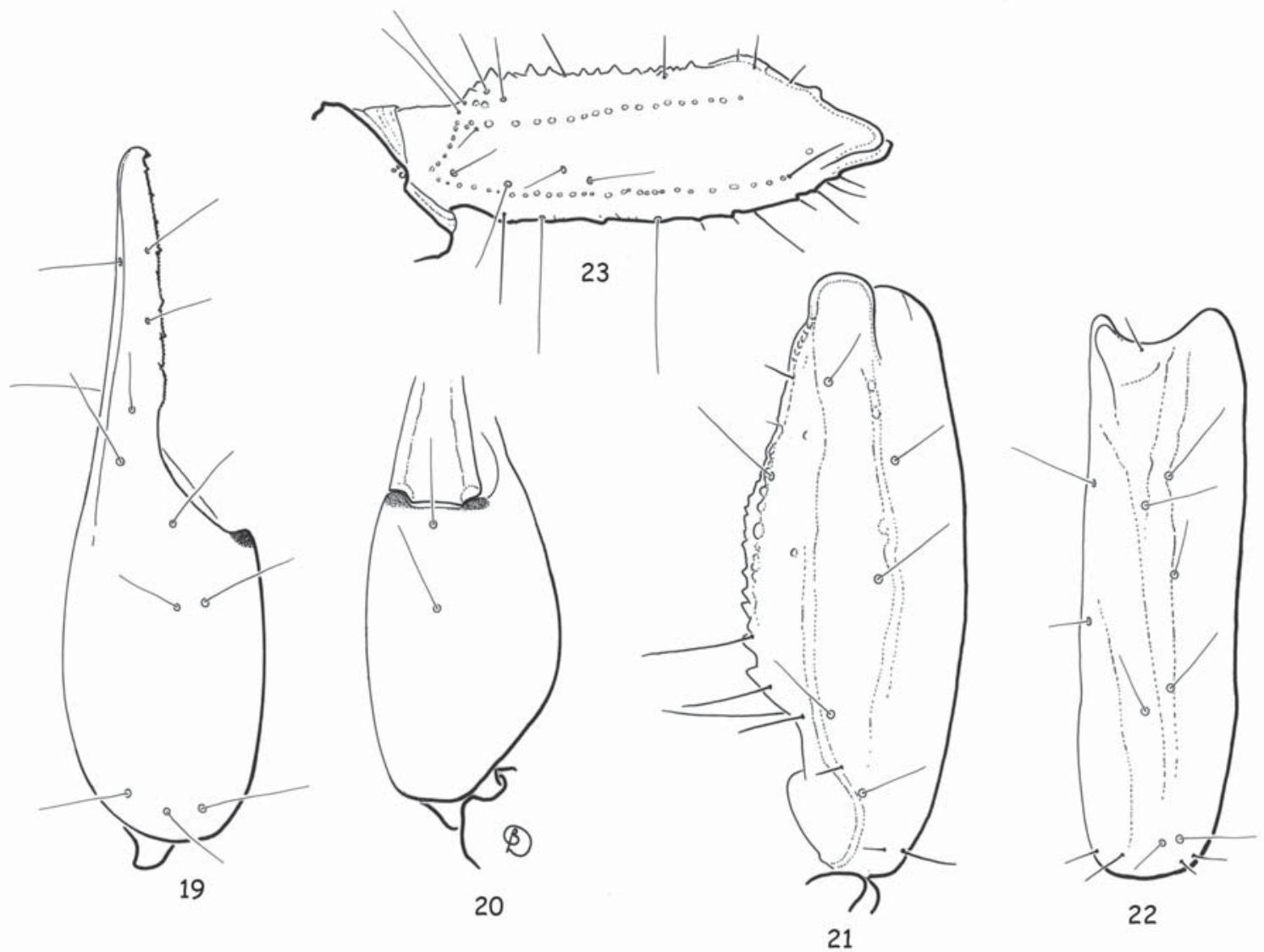

Figs 19-23. Buthacus golovatchi sp.n., holotype, trichobothrial pattern: $19 \& 20-$ chela, dorso-external and ventral aspects, respectively; $21 \& 22$ - patella, dorsal and external aspects, respectively; 23 - femur, dorsal aspect.

Рис. 19-23. Buthacus golovatchi sp.n., голотип, распределение трихоботрий: 19 и 20 - хела, соответственно снаружи и сверху и снизу; 21 и 22 - пателла, соответственно сверху и снизу; 23 - бедро, сверху.

PARATYPES: $1 \sigma^{\pi}$, same locality, together with holotype; 1 $\mathrm{O}^{7}$, Chad, Ennedi, Daiba-Baba, confluence O. Nohi, 560 m, IX.1958, leg. J. Mateu.

NAME. Honours Sergei I. Golovatch, Russian Academy of Sciences, Moscow, for his support to the publication of this paper.

DIAGNOSIS. Scorpions of moderate size in relation to the other congeners, with a total length of $40-45 \mathrm{~mm}$ for $\sigma^{7} \sigma^{7}$. General coloration yellowish to pale yellow, without spots. Pedipalps with 8 or 9 rows of granules on fixed and movable fingers; internal and external accessory granules present, but represented by moderate to small basal granules; granulation not masked by setation. Trichobothriotaxy A- $\beta$ orthobothriotaxic. Latero-ventral carinae on segment $\mathrm{V}$ with spinoid granules, any marked lobe absent. Tibial spurs moderate to weak on legs III and IV. Pectinal tooth count 26 to 29 in $\sigma^{\top} \sigma^{\top}$.

RELATIONSHIPS. The new species seems to be especially similar to Buthacus leptochelys (Ehrenberg, 1829). It can be distinguished, however, from this latter species by the following characters: (i) paler coloration, (ii) pectinal tooth count shows fewer teeth; 26-29 vs $32-35$, (iii) absence of lobes on latero-ventral carinae of metasomal segment $\mathrm{V}$, (iv) a distinct geographical distribution.

DESCRIPTION. Coloration: Generally yellowish to pale yellow, with neither any spots nor pigmented zones on body and appendages. Prosoma: Carapace yellowish; only eyes surrounded by black pigment. Mesosoma yellowish, paler in median zone. Metasoma: All segments yellowish. Vesicle yellowish; aculeus yellowish at base and reddish at its extremity. Venter yellowish; pectines pale yellow. Chelicerae yellowish; teeth reddish. Pedipalps yellowish overall; rows of granules at dentate margins of fingers reddish. Legs yellowish, paler than body.

Prosoma: Anterior margin of carapace not emarginate, straight. Carapace carinae weakly developed; anterior median carinae obsolete; central median, posterior median and central lateral carinae weak. All furrows weak to obsolete. Intercarinal spaces weakly granular. Median ocular tubercle slightly anterior to centre of carapace; median eyes separated by 1.5 ocular diameters. Five pairs of lateral eyes; first three arranged in one line, fourth and fifth situated behind eye three. Mesosoma: Tergites I-VI tricarinate; all carinae very weak; lateral carinae vestigial in segment I; tergite VII 
pentacarinate, with lateral pairs of carinae moderate; median carinae present in proximal half, moderately marked. Intercarinal spaces weakly granular to smooth. Sternites: Carinae absent from sternites III-VI; moderate to weak on VII. Pectines long; pectinal tooth count 26 or 27 in holotype and 26 or 27,28 or 29 in paratypes. Metasoma: Segments I and II with 10 carinae; III and IV with 8 carinae. Ventral carinae vestigial in segment I, weak in II, moderate in III and IV; dorsal carinae with slightly spinoid granules in segments I and II. Segment V with five carinae; ventrolateral armed with spinoid granules, but without lobes. Dorsal furrows in all segments weakly developed, smooth; intercarinal spaces not granular, smooth. Telson smooth. Aculeus longer than vesicle; subaculear tubercle absent. Chelicerae: Movable finger with external distal tooth shorter than internal distal; two strongly reduced, but not fused denticles at base of movable finger [Vachon, 1963]. Pedipalps: Trichobothrial pattern orthobothriotaxic, type A as difined by Vachon [1974]; dorsal trichobothria of femur in $\beta$ configuration [Vachon, 1975]. Femur pentacarinate; all carinae moderately crenulate. Patella with 7 or 8 vestigial carinae; chela without carinae, smooth. Dentate margins on fixed and movable fingers composed of 8 or 9 almost linear rows of granules; internal and external accessory granules represented by moderate to small basal granules; granulation not masked by setation. Legs: Ventral aspect of tarsi with numerous long thin setae; general setation typical of a psammophilous species. Tibial spurs moderate to weak on legs III and IV. Pedal spurs moderate on all legs.

Morphometric values (in $\mathrm{mm}$ ) of holotype. Total length, $44.1\left(50.0^{*}\right)$. Carapace: length, 4.9; anterior width, 3.2; posterior width, 5.6. Mesosoma length, 12.6. Metasomal segments. I: length, 4.2; width, 3.3; V: length, 6.4; width, 2.4; depth, 2.4. Telson length, 5.9. Vesicle: width, 1.8; depth, 1.7. Pedipalp: femur length, 4.5, width, 1.3; patella length, 5.3 , width, 1.8 ; chela length, 8.4, width, 2.3, depth, 2.4; movable finger length, 4.7. (* Including telson length).

Butheoloides Hirst, 1925

Subgenus Butheoloides Hirst, 1925

\section{Butheoloides (s.str.) granulatus sp.n.} Figs 24-34.

HOLOTYPE + , Chad, Ennedi, Basso, 986 m, 15.IX.1958, leg. J. Mateu.

NAME. The specific name refers to the intense granulation present in the new species.

DIAGNOSIS. Scorpions of moderate size in relation to that of the other congeners; holotype $20.1 \mathrm{~mm}$ in total length. Coloration generally reddish-yellow to reddish-brown; chelicerae with variegated pigmentation. Carapace strongly emarginated. Carapace and tergites with a moderately marked granulation. Dorsal carinae of metasomal segments moderately marked; all segments and telson with moderately to strongly marked granulations; aculeus strongly curved and shorter than vesicle; subaculear tooth strong and conical. Pectinal tooth count 14-14; fulcra present. Pedipalps moderately short; fixed and movable fingers with 10 or 11 rows of granules; internal accessory granules present, conspicuous; distal extremity of movable finger with three teeth. Trichobothrial pattern: $\alpha-\beta$ orthobothriotaxy.

RELATIONSHIPS. The new species can be distinguished from the other species of the genus by a combination of distinct characters: (i) body and appendages more uniformly dark brown, (ii) carapace, tergites, metasoma and pedipalps intensely granulated, (iii) very important setation on metasomal segments and telson.

DESCRIPTION. Coloration: Basically reddish-yellow to reddish-brown. Prosoma: Carapace brownish; median and lateral eyes surrounded by black pigment. Mesosoma: Tergites I to VII brownish; VII with some yellowish spots. Metasomal segments I to V reddishbrown; IV and V darker than other segments; telson yellow with aculeus reddish at tip. Venter yellowish; pectines pale yellow. Chelicerae yellow with variegated spots; fingers yellow with reddish teeth. Pedipalps reddish-brown with base of chelal fingers very dark; legs pale yellow, slightly infuscated.

Carapace with moderately marked granulations; anterior margin strongly emarginated. Carinae and furrows weak to vestigial. Median ocular tubercle markedly anterior to centre of carapace; median eyes separated by one ocular diameter. Three pairs of lateral eyes. Sternum pentagonal, wider than long. Mesosoma: Tergites with moderately marked granulations and punctations; median carina weakly marked on all tergites; tergite VII pentacarinate, with carinae weakly marked. Venter: Genital operculum divided longitudinally, formed by two almost subtriangular plates. Pectinal tooth count 14-14; fulcra conspicuous. Sternites smooth with small slit-like spiracles; VII smooth, without carinae. Metasomal segments I to V rounded; dorsal and dorso-lateral carinae present in segments IIV; all segments with moderately to strongly marked granulations. Telson moderately to strongly granular; aculeus shorter than vesicle, strongly curved; subaculear tooth conical, strongly marked. Cheliceral dentition characteristic of Buthidae [Vachon, 1963]; movable fingers with two basal teeth, small, spinoid and not fused; ventral aspect of both finger and manus with setae. Pedipalps: Femur pentacarinate; patella with dorsal and dorso-internal carinae moderately to strongly marked; chela without carinae, smooth; all faces weakly granular to smooth. Fixed and movable fingers of pedipalps with 10 or 11 oblique rows of granules, with accessory granules as well; three granules at extremity of movable finger. Trichobothriotaxy: A- $\beta$ orthobothriotaxy [Vachon, 1974, 1975]. Legs: Tarsus with setae ventrally. Pedal spurs present on legs I-IV; tibial spurs moderately marked on legs III and IV.

Morphometric values (in $\mathrm{mm}$ ) of holotype. Total length, $20.1\left(22.5^{*}\right)$. Carapace: length, 2.6; anterior width, 1.5; posterior width, 2.4. Mesosoma length, 6.6. 


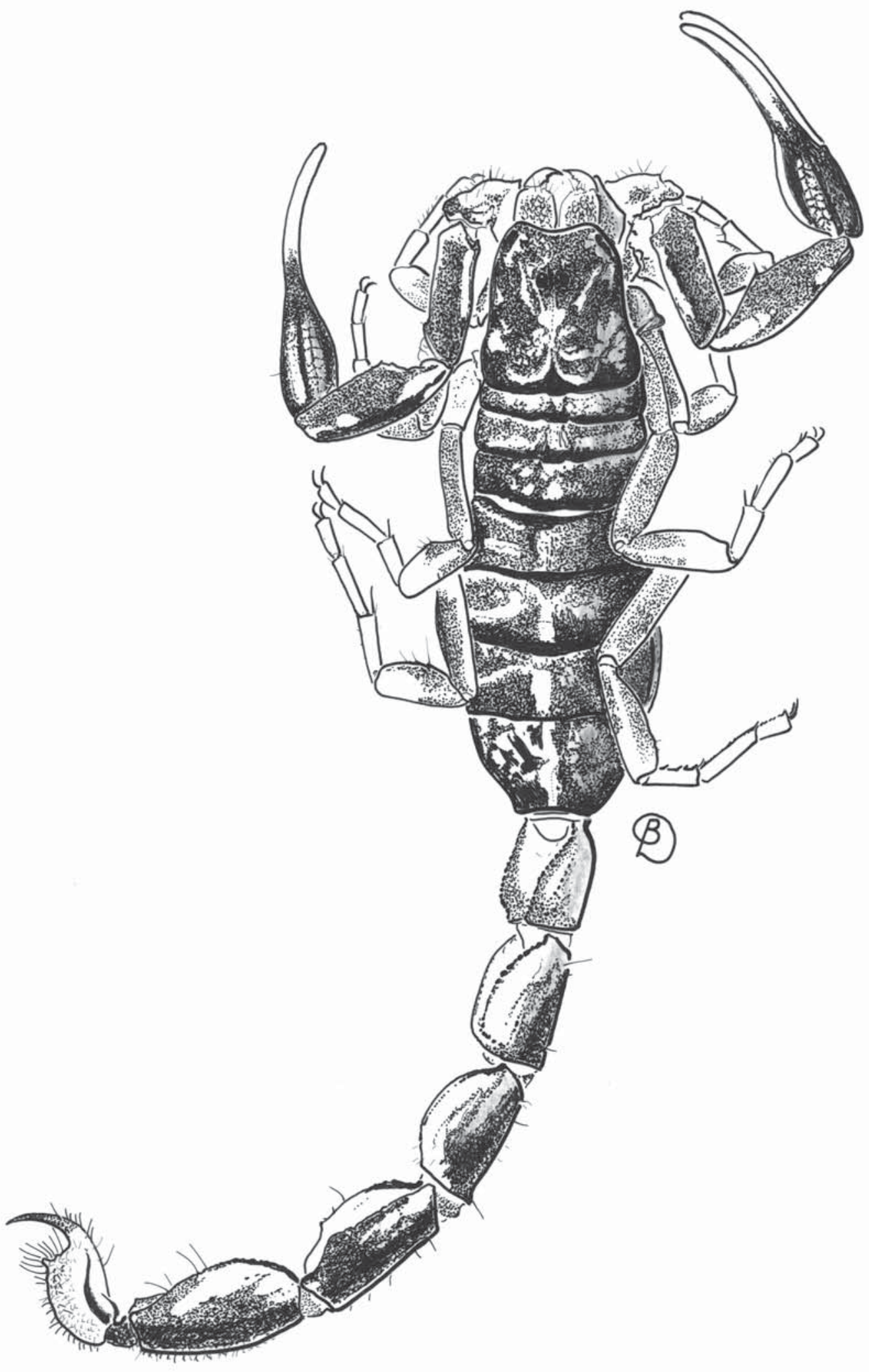

Fig. 24. Butheoloides (s.str.) granulatus sp.n., holotype, habitus.

Рис. 24. Butheoloides (s.str.) granulatus sp.n., голотип, габитус. 

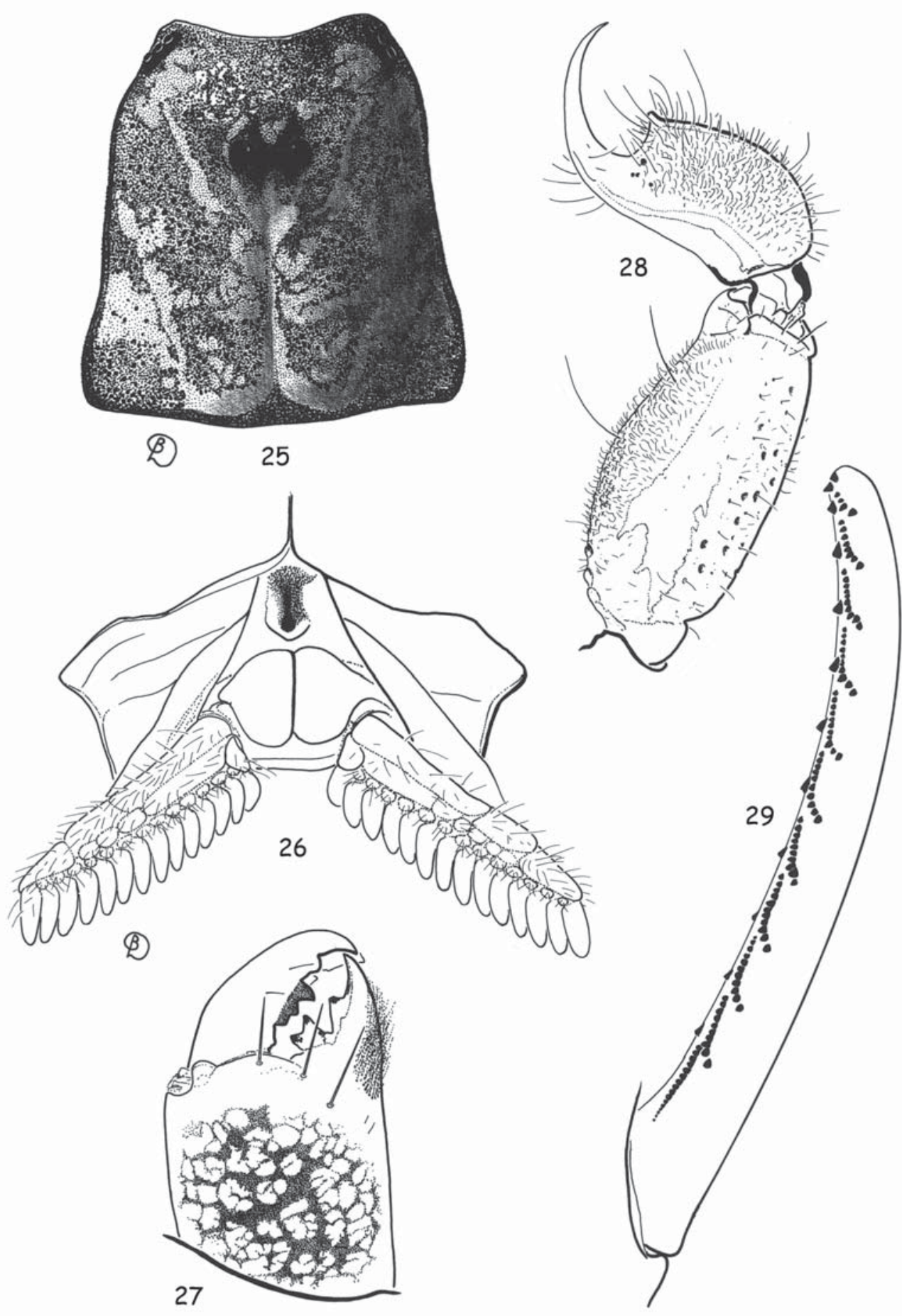

Figs 25-29. Butheoloides (s.str.) granulatus sp.n., holotype: 25 - carapace, dorsal aspect; 26 - coxapophysis, sternum, genital operculum and pectines; 27 - chelicera, dorsal aspect; 28 - metasomal segment $\mathrm{V}$ and telson, lateral aspect; 29 - cutting edge of movable finger with rows of granules.

Рис. 25-29. Butheoloides (s.str.) granulatus sp.n., голотип: 25 - карапакс, сверху; 26 - коксапофиз, стернит, крышечка гениталий и пектины; 27 - хелицера, сверху; 28 - сегмент V метасомы и тельсон, сбоку; 29 - режущий край подвижного пальца с рядами гранул. 


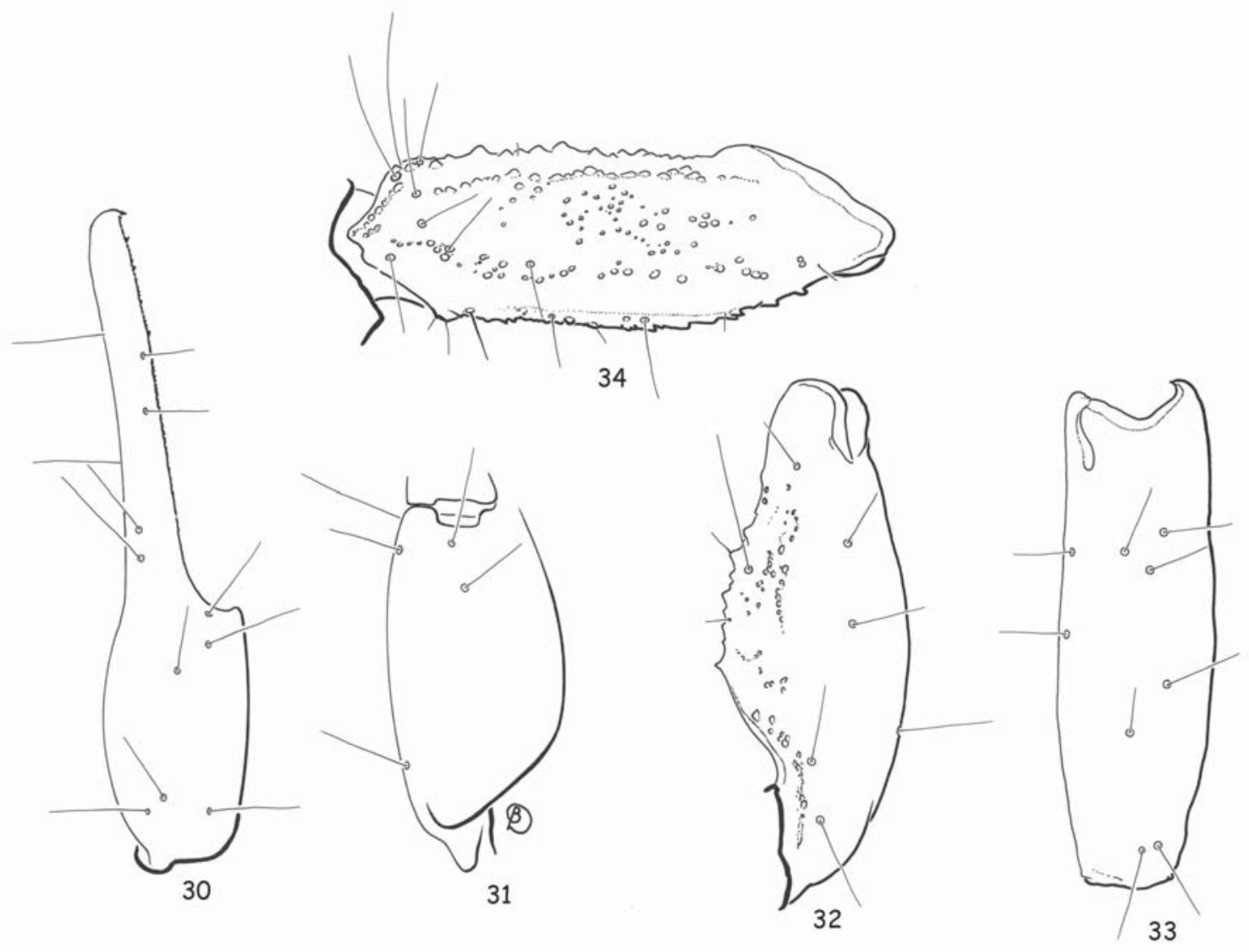

Figs 30-34. Butheoloides (s.str.) granulatus sp.n., holotype, trichobothrial pattern: 30 \& 31 - chela, dorso-external and ventral aspects, respectively; $32 \& 33$ - patella, dorsal and external aspects, respectively; 34 - femur, dorsal aspect.

Рис. 30-34. Butheoloides (s.str.) granulatus sp.n., голотип, распределение трихоботрий: 30 и 31 - хела, соответственно снаружи и сверху и снизу; 32 и 33 - пателла, соответственно сверху и снизу; 34 - бедро, сверху.

Metasomal segments. I: length, 1.7; width, 1.5; V: length, 2.5; width, 1.6; depth, 1.2. Telson length, 2.4. Vesicle: width, 1.2; depth, 0.9. Pedipalp: femur length, 2.2, width, 0.7 ; patella length, 2.6 , width, 1.0 ; chela length, 4.2 , width, 0.9 , depth, 0.8 ; movable finger length, 2.8. (* Including telson length).

Buthus Leach, 1815

\section{Buthus hassanini sp.n.}

Figs 35-42.

HOLOTYPE ․, Chad, Ennedi Plateau, Biti Tehëc, 1,100 m, under stone, 13.IX.1958, leg. J. Mateu.

NAME. Honours Alexandre Hassanin, Université Pierre et Marie Curie-MNHN, Paris, for his interest in the study of scorpion phylogeny.

DIAGNOSIS. Scorpions of small to medium size in relation to the other congeners, reaching a total length of $40.5 \mathrm{~mm}$ in + . General coloration yellow to pale yellow; longitudinal stripes absent from tergites; telson yellowish to pale yellow with tip of aculeus dark reddish. Venter yellowish. Pedipalps yellowish; legs pale yellow. Chelicerae yellowish with reddish teeth. Anterior margin of carapace with a weakly marked concavity; carinae and granulations moderately to weakly marked. Fixed and movable fingers with 11 or 12 rows of granules. Pectines with 26-26 teeth in + .

RELATIONSHIPS. Buthus hassanini sp.n. belongs to the "Buthus occitanus" complex of species. It can be distinguished from the other species of Buthus, in particular from B. brignolii Lourenço, 2003, distributed in the Darfur region in Sudan, by the following characters: (i) paler overall coloration, yellowish to pale yellow, without dark longitudinal stripes over carapace and tergites, (ii) anterior margin of carapace with a weak concavity, (iii) carinae on carapace, tergites and metasoma moderately to weakly marked, (iv) chelal fingers with 11 or 12 rows of granules; pectines with 26 teeth.

DESCRIPTION. Coloration: Mainly yellowish, without longitudinal dark stripes on tergites. Prosoma: Carapace yellowish; eyes and anterior median carinae marked by dark pigment. Mesosoma yellowish. Metasoma: Segments I to V yellowish; vesicle yellowish; aculeus yellowish at its base and dark reddish at its extremity. Venter yellowish; pectines pale yellow. Che- 

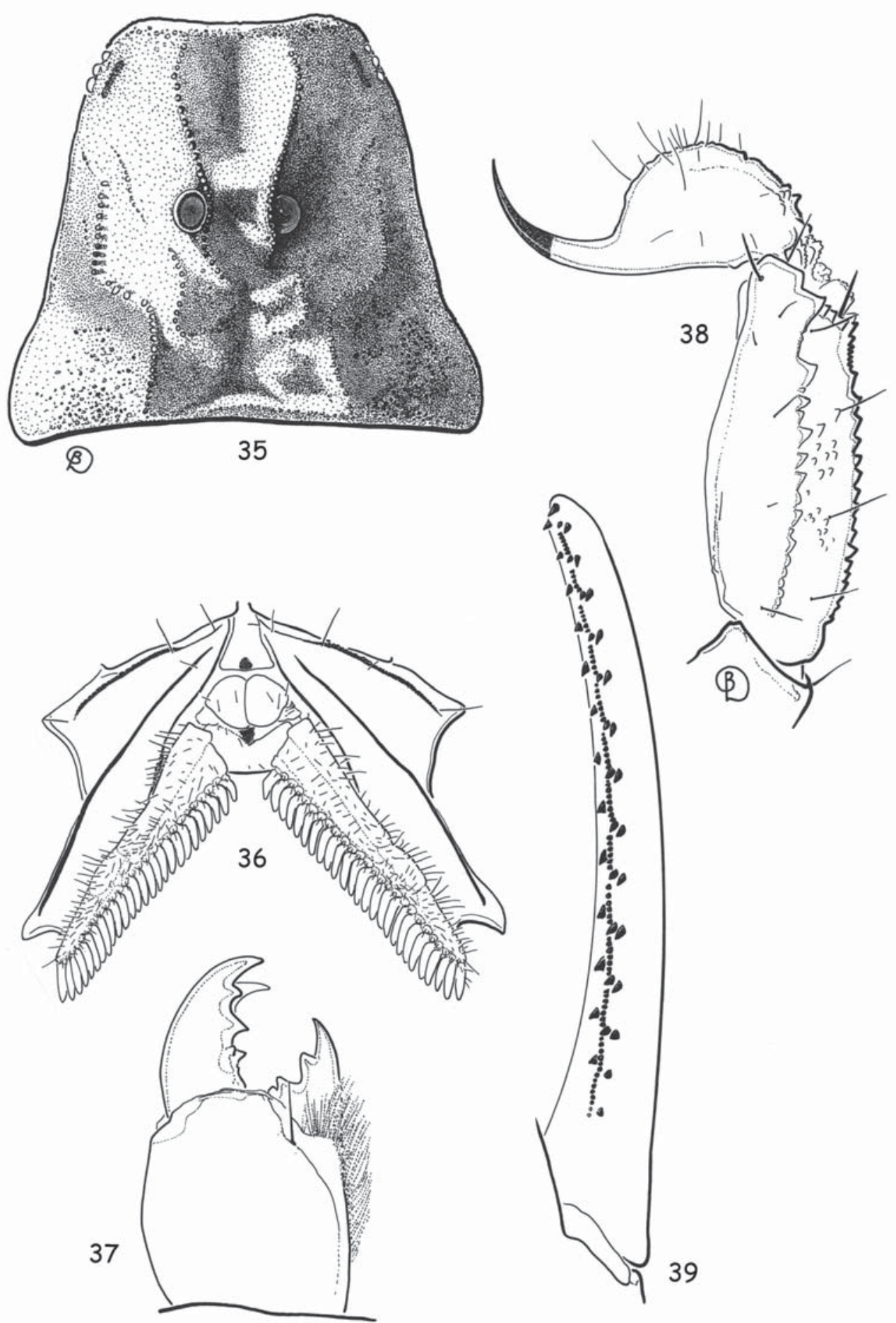

Figs 35-39. Buthus hassanini sp.n., holotype: 35 - carapace, dorsal aspect; 36 - coxapophysis, sternum, genital operculum and pectines; 37 - chelicera, dorsal aspect; 38 - metasomal segment $V$ and telson, lateral aspect; 39 - cutting edge of movable finger with rows of granules.

Pис. 35-39. Buthus hassanini sp.n., голотип: 35 - карапакс, сверху; 36 - коксапофиз, стернит, крышечка гениталий и пектины; 37 - хелицера, сверху; 38 - сегмент V метасомы и тельсон, сбоку; 39 - режущий край подвижного пальца с рядами гранул. 


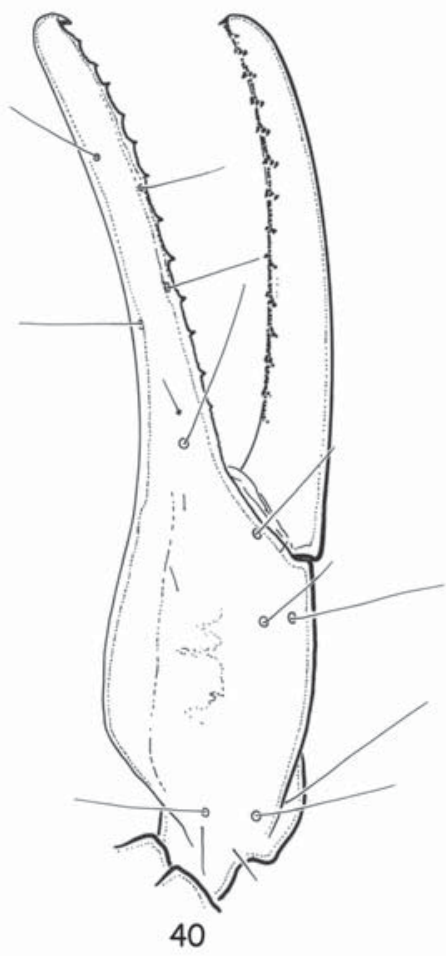

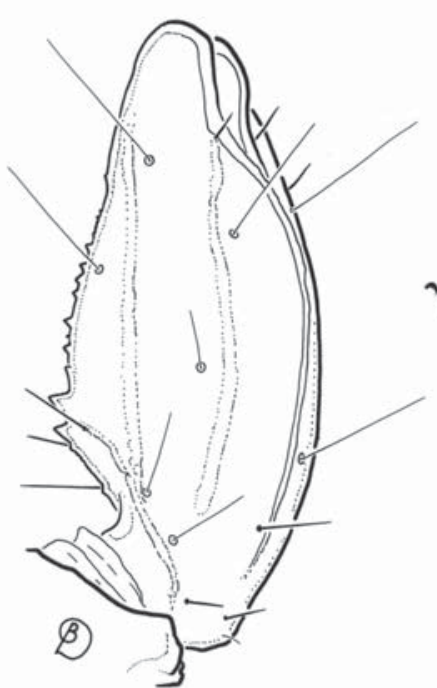

41

Figs 40-42. Buthus hassanini sp.n., holotype, trichobothrial pattern: 40 - chela, dorso-external aspect; 41 — patella, dorsal aspect; 42 - femur, dorsal aspect.

Рис. 40-42. Buthus hassanini sp.n., голотип, распределение трихоботрий: 40 - хела, снаружи и сверху; 41- пателла, сверху; 42 - бедро, сверху.

licerae yellowish, without variegated spots; fingers yellowish with reddish teeth. Pedipalps yellowish; hand of chela slightly infuscated; fingers with oblique rows of granules reddish. Legs pale yellow, with neither any diffuse nor fuscous spots.

Carapace moderately granular; anterior margin with a weak concavity. Carinae moderate; anterior median moderately granular, central median and posterior median carinae moderately to weakly granular, with 'lyre' configuration; posterior lateral carinae weakly marked to vestigial. All furrows moderate. Median ocular tubercle at centre of carapace. Eyes separated by almost three ocular diameters. Four pairs of lateral eyes: first three of moderate size, last only vestigial. Sternum triangular, wider than long. Mesosoma: Tergites moderately to weakly granular. Three weakly crenulate longitudinal carinae on all tergites; lateral carinae reduced on tergites I and II. Tergite VII pentacarinate. Venter: Genital operculum divided longitudinally, forming two subtriangular plates. Pectines: Pectinal tooth count 26-26 in holotype; middle basal lamella of pectines not dilated. Sternites with some thin granules, almost smooth, with elongated spiracles; four carinae on sternite VII; other sternites acarinated, with two vestigial furrows. Metasoma: Segments I to III with 10 crenulated carinae, ventral moderately to strongly marked in II and III; segment IV with eight carinae, crenulated; first four segments each with a smooth dorsal depression; segment $\mathrm{V}$ with five carinae; lateroventral carinae crenulated, with 2 or 3 lobate denticles posteriorly; ventral median carina slightly divided posteriorly; anal arc composed of 7 or 8 ventral teeth and with two lateral lobes. Intercarinal spaces weaky granular. Telson with moderately marked granulations on ventral surface; aculeus curved and shorter than vesicle, without a subaculear tooth. Cheliceral dentition as defined by Vachon [1963] for the family Buthidae; external distal and internal distal teeth subequal in length; basal teeth on movable finger small and totally fused; ventral aspect of both fingers and manus covered with long dense setae. Pedipalps: Femur pentacarinate; patella with eight carinae; chela with 4 or 5 vestigial carinae on dorso-external surface; all faces weakly granular to smooth. Fixed and movable fingers with 11 or 12 oblique rows of granules. Internal and external accessory granules present, moderate to strong; three accessory granules at distal end of movable finger next to terminal denticle. Trichobothriotaxy: Trichobothrial pattern of type A, orthobothriotaxic as defined by Vachon [1974]. Dorsal trichobothria of femur arranged in $\beta$ configuration [Vachon, 1975]. Legs: Tarsus with two longitudinal rows of 6 or 7 setae ventrally; tibial spurs strong on legs III and IV; pedal spurs moderate to strong on legs I to IV. 

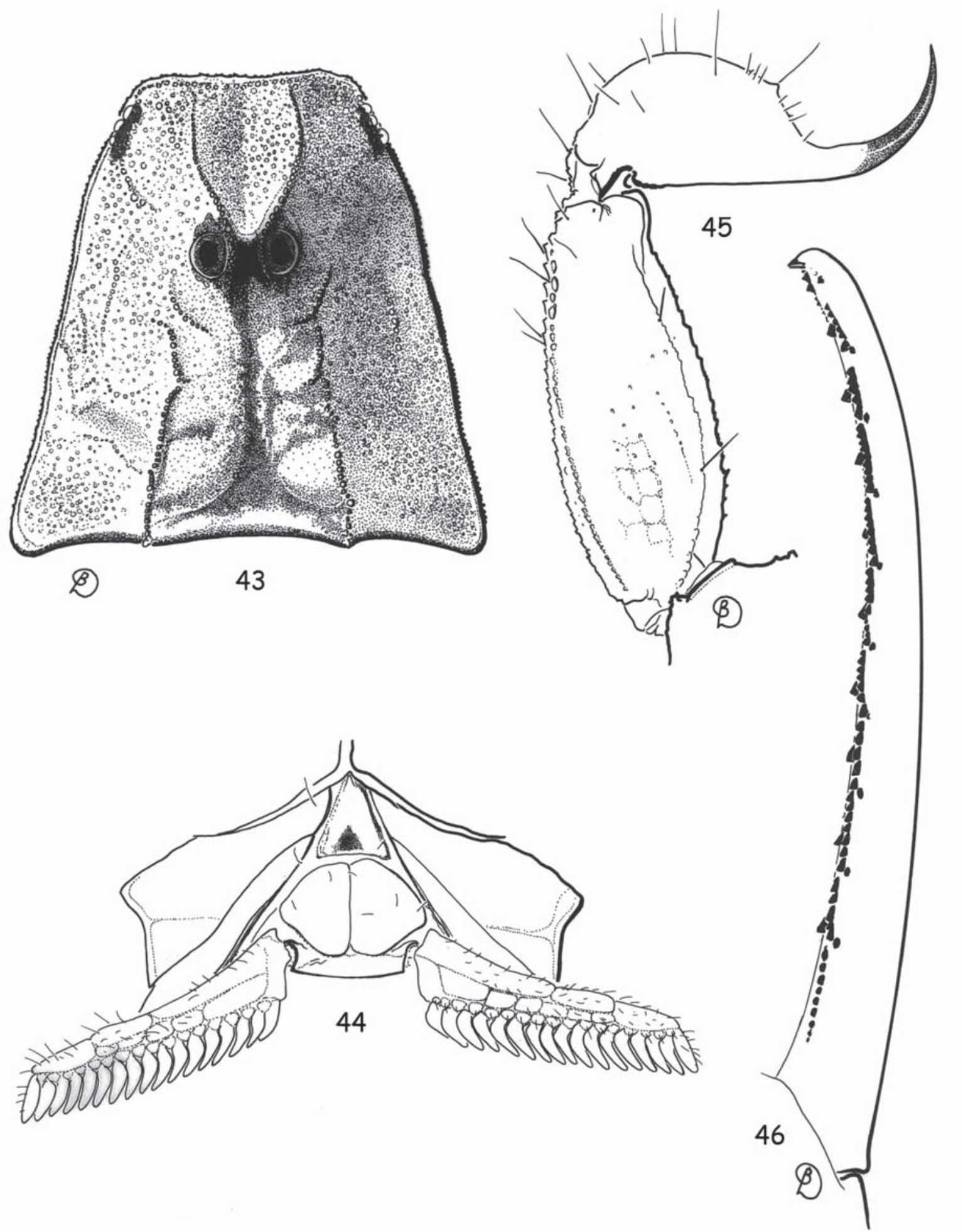

Figs 43-46. Compsobuthus boucheti sp.n., holotype: 43 - carapace, dorsal aspect; 44 — coxapophysis, sternum, genital operculum and pectines; 45 - metasomal segment $\mathrm{V}$ and telson, lateral aspect; 46 - cutting edge of movable finger with rows of granules.

Рис. 43-46. Compsobuthus boucheti sp.n., голотип: 43 - карапакс, сверху; 44 - коксапофиз, стернит, крышечка гениталий и пектины; 45 - хелицера, сверху; 46 - сегмент V метасомы и тельсон, сбоку; 47 - режущий край подвижного пальца с рядами гранул. 


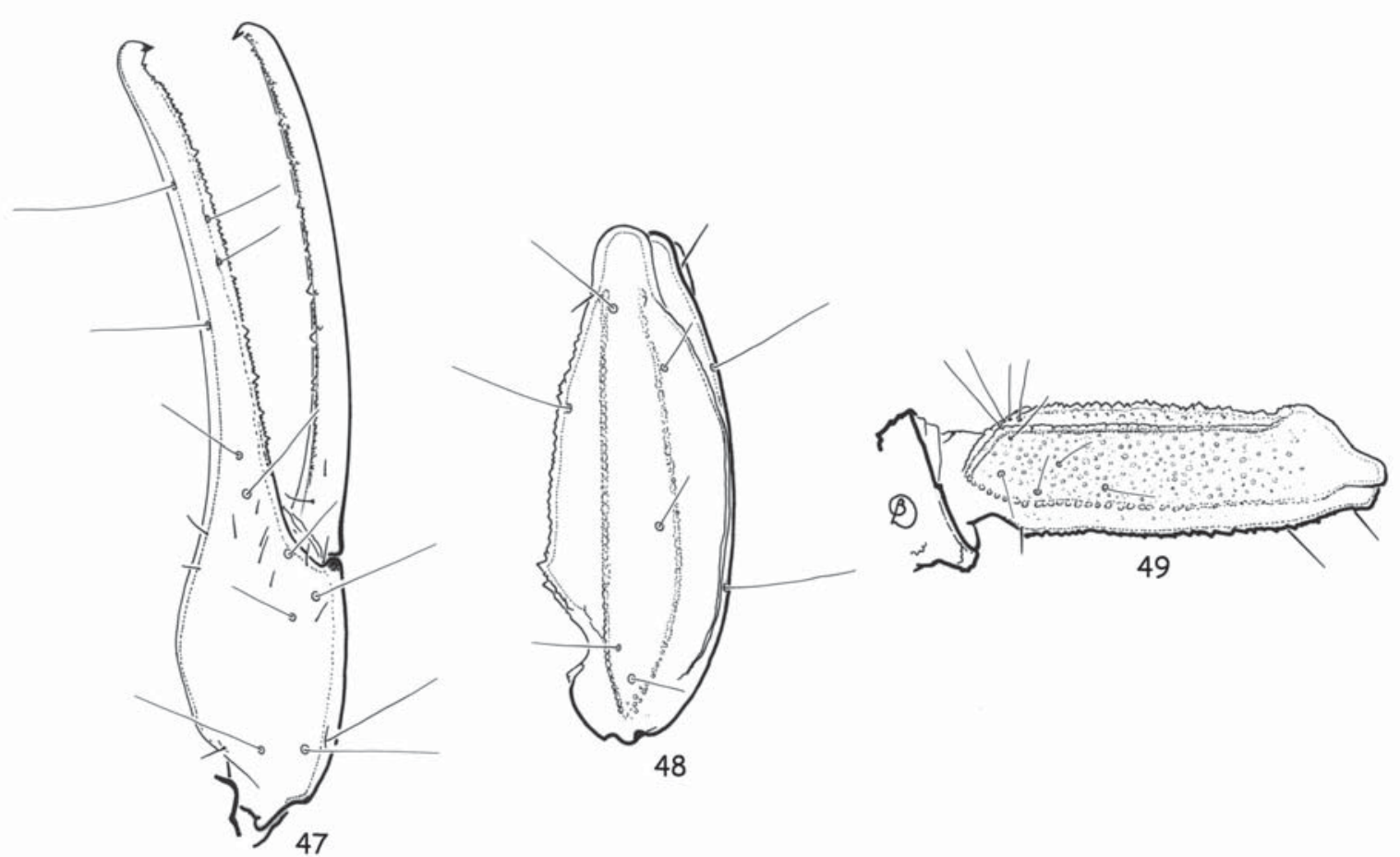

Figs 47-49. Compsobuthus boucheti sp.n., holotype, trichobothrial pattern: 47 - chela, dorso-external aspect; 48 - patella, dorsal aspect; 49 - femur, dorsal aspect.

Рис. 47-49. Compsobuthus boucheti sp.n., голотип, распределение трихоботрий: 47 - хела, снаружи и сверху; 48 - пателла, сверху; 49 - бедро, сверху.

Morphometric values (in $\mathrm{mm}$ ) of holotype. Total length, $40.5(45.2 *)$. Carapace: length, 4.9; anterior width, 3.3; posterior width, 5.6. Mesosoma length, 13.2. Metasomal segments. I: length, 3.4; width, 3.3; V: length, 5.6; width, 2.8; depth, 2.3. Telson length, 4.7. Vesicle: width, 2.1; depth, 1.9. Pedipalp: femur length, 3.7, width, 1.3; patella length, 4.3 , width, 1.9; chela length, 7.7, width, 1.7, depth, 1.7; movable finger length, 5.3. (* Including telson length).

Compsobuthus Vachon, 1949

\section{Compsobuthus boucheti sp.n.}

Figs 43-49.

HOLOTYPE o, Chad, NW, Ennedi, Nohi, Chillio, $536 \mathrm{~m}$, 26.VIII.1958, leg. J. Mateu.

NAME. Honours Philippe Bouchet, MNHN, Paris, for his former support to our research.

DIAGNOSIS. Scorpions of medium size in relation to the other congeners, reaching a total length of 28.0 $\mathrm{mm}$ in 9 . General coloration yellowish to pale yellow with infuscated zones on carapace and metasomal segment V. Carinae and granulations moderately developed. Sternites smooth. Pectines moderately long; pectinal tooth count $17-17$ in ${ }^{\circ}$. Metasomal segments I-V with 10-10-8-8-5 carinae; intermediate carinae not complete in II. Telson weakly granular; aculeus shorter than vesicle; subaculear tubercle weak, rhomboid. Tri- chobothrial pattern orthobothriotaxic, type A- $\beta$. Chela with moderately elongated fingers. Dentate margins on movable and fixed fingers composed of 9 or 10 almost linear rows of granules; inner accessory granules moderately to strongly marked; outer accessory granules weakly marked or absent.

RELATIONSHIPS. The new species shows especially apparent affinities to C. werneri (Birula, 1908), but it can be distinguished from this latter species by the following characters: (i) outer accessory granules on chelal fingers weakly marked or absent, (ii) better marked granulation on metasomal segments and telson, (iii) carinae of carapace less marked, (iv) aculeus shorter than vesicle, (v) incomplete intermediate carinae in metasomal segment II.

DESCRIPTION. Coloration: Generally yellowish to pale yellow with infuscated zones on carapace and metasomal segment $\mathrm{V}$; eyes surrounded by black pigment. Vesicle yellowish; aculeus yellowish at base and reddish at tip. Chelicerae yellowish, with slightly reddish teeth. Pedipalps overall yellowish; rows of granules at dentate margins of fingers reddish. Legs and venter pale yellow.

Prosoma: Anterior margin of carapace weakly emarginate. Carapace carinae moderately developed; anterior median, central median, posterior median and central lateral moderately marked; posterior median carinae terminating distally in a small spinoid process that extends beyond the posterior margin of the cara- 


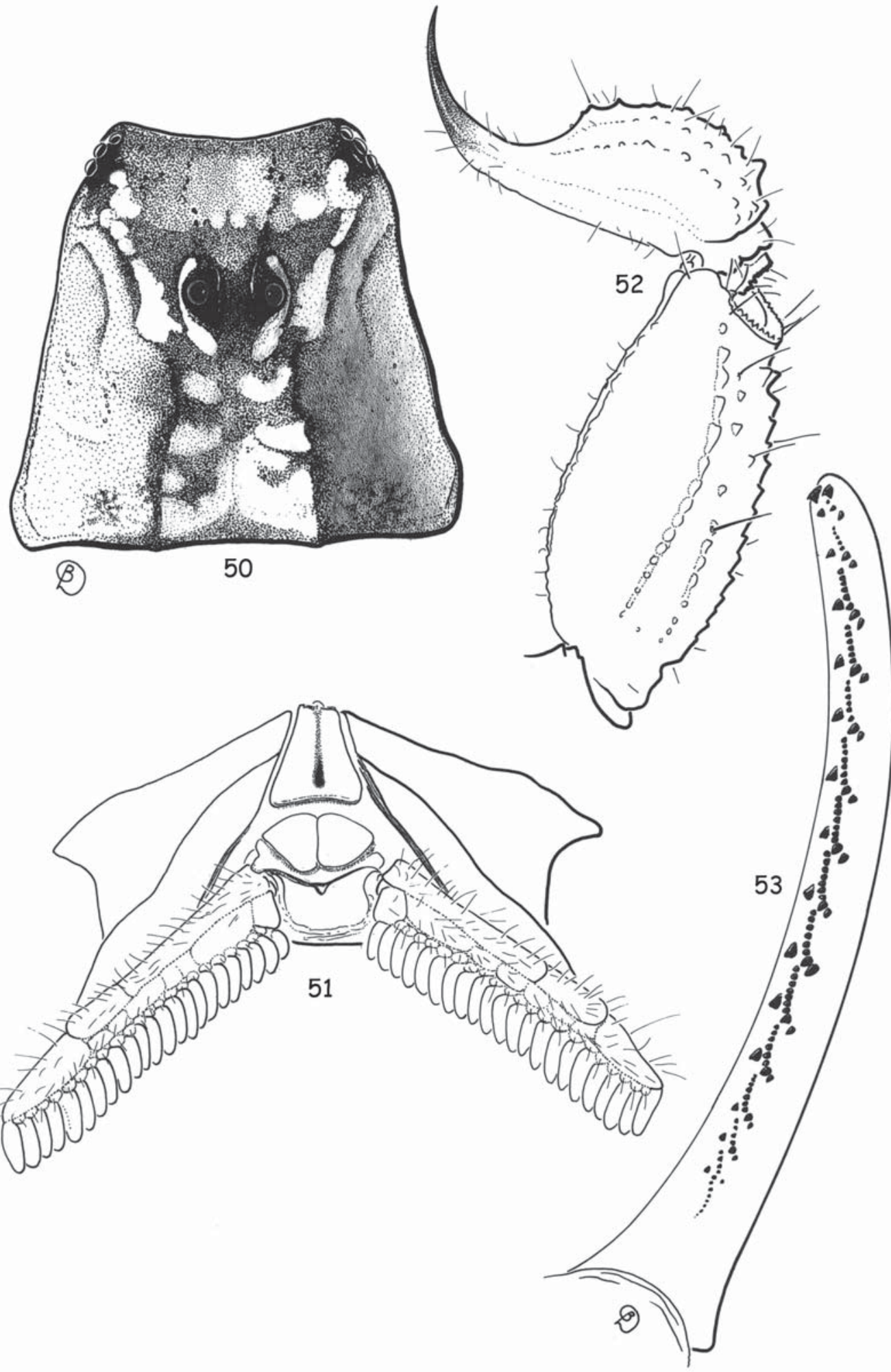

Figs 50-53. Hottentotta mateui sp.n., holotype: 50 - carapace, dorsal aspect; 51 - coxapophysis, sternum, genital operculum and pectines; 52 - metasomal segment $\mathrm{V}$ and telson, lateral aspect; 53 - cutting edge of movable finger with rows of granules.

Рис. 50-53. Hottentotta mateui sp.n., holotype: 50 - карапакс, сверху; 51 - коксапофиз, стернит, крышечка гениталий и пектины; 52 - сегмент V метасомы и тельсон, сбоку; 53 - режущий край подвижного пальца с рядами гранул. 


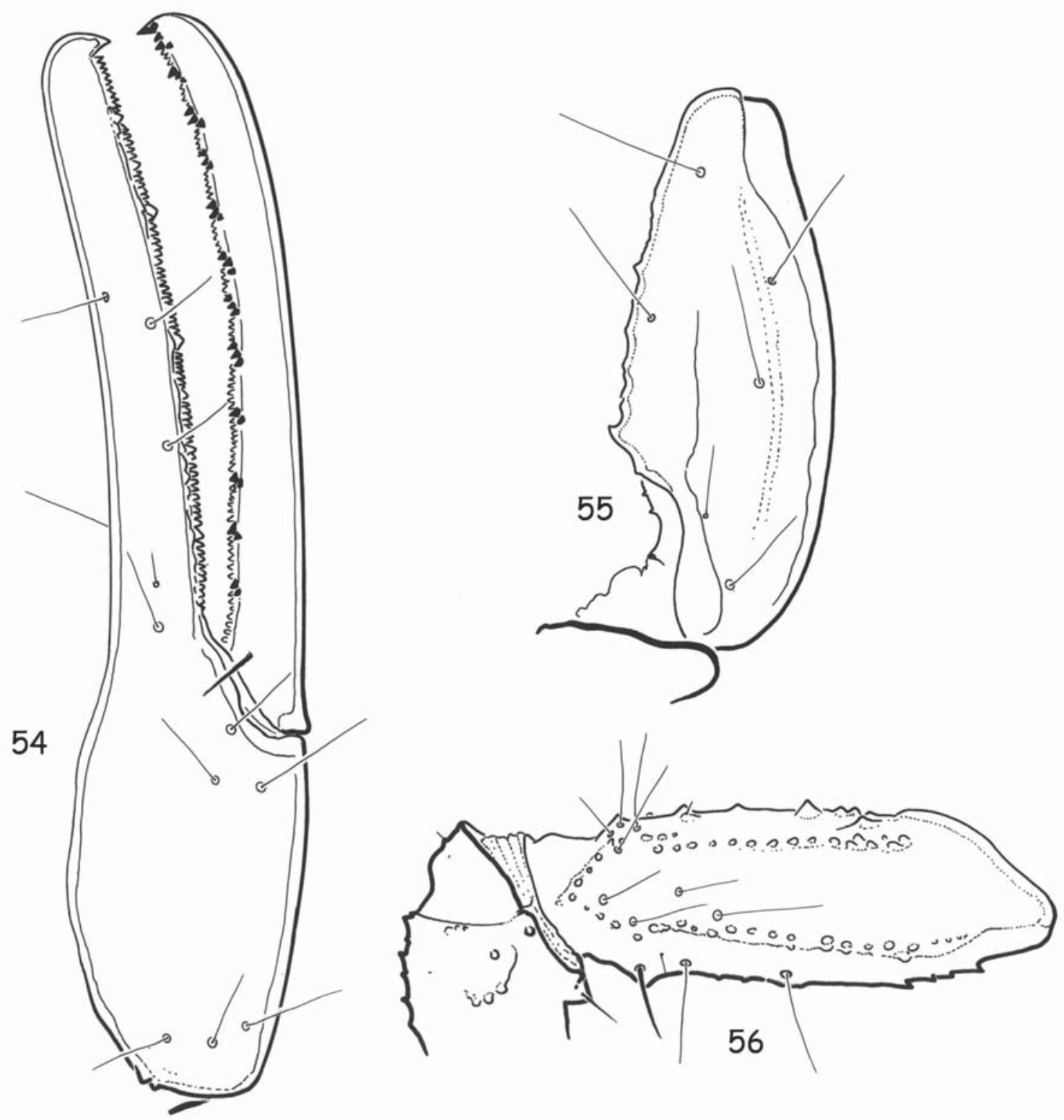

Figs 54-56. Hottentotta mateui sp.n., holotype, trichobothrial pattern: 54 - chela, dorso-external aspect; 55 - patella, dorsal aspect; 56 - femur, dorsal aspect.

Рис. 54-56. Hottentotta mateui sp.n., голотип, распределение трихоботрий: 54 — хела, снаружи и сверху; 55 — пателла, сверху; 56 - бедро, сверху.

pace. Intercarinal spaces weakly to moderately granular; almost smooth centrally. Median ocular tubercle anterior to centre of carapace; median eyes separated by one ocular diameter. Three pairs of lateral eyes. Mesosoma: Tergites I-VI tricarinate. Lateral carinae on I-VI strongly marked; each carina terminating distally in a spinoid process that extends strongly beyond the posterior margin of the tergite. Median carinae in I weak; in II-VI moderate to strong, crenulate; terminating distally in each segment in a spinoid process that extends slightly beyond the posterior margin of the tergite. Tergite VII pentacarinate, with lateral pairs of carinae moderate to strong; median carinae present in proximal half, moderate. Intercarinal spaces moderately granular. Sternites: Lateral carinae absent from sternites III-VI; moderate, finely crenulate on VII. Submedian carinae absent from all sternites. Pectines moderately long; pectinal tooth count $17-17$ in 9 . Metasoma: Segments I and II with ten carinae, crenulate; intermediate carinae not complete in II; III and IV with eight carinae. Segment V with five carinae; ventromedian carinae moderate to weak. Dorsal furrows of all segments weakly developed and weakly granulated; intercarinal spaces moderately granular. Telson weakly granular. Subaculear tubercle weak, rhomboid. Cheliceral dentition as defined by Vachon [1963] for 
Buthidae; movable finger with external distal tooth slightly shorter than internal distal tooth, basal teeth strongly reduced and partly fused; ventral aspect of both finger and manus covered with setae. Pedipalps: Trichobothrial pattern orthobothriotaxic, type A [Vachon, 1974]; dorsal trichobothria of femur in $\beta$ configuration [Vachon, 1975]. Femur pentacarinate; all carinae moderately crenulate. Patella with eight carinae; all carinae moderately marked; dorso-internal carinae each with one spinoid granule. Chela moderately slender, with moderately elongated fingers; all carinae moderately marked. Dentate margins on movable and fixed fingers composed of 9 or 10 almost linear rows of granules; inner accessory granules moderately to strongly marked; outer accessory granules weakly marked or absent. Legs: Ventral aspect of tarsi with two rows of setae. Tibial spurs present on legs III and IV, moderate. Pedal spurs present, moderate in all legs.

Morphometric values (in $\mathrm{mm}$ ) of holotype. Total length, $28.4\left(31.9^{*}\right)$. Carapace: length, 3.9; anterior width, 2.3; posterior width, 3.8. Mesosoma length, 8.4. Metasomal segments. I: length, 2.5; width, 2.2; V: length, 4.0; width, 1.6; depth, 1.6. Telson length, 3.5. Vesicle: width, 1.3; depth, 1.3. Pedipalp: femur length, 3.3 , width, 1.0 ; patella length, 4.0 , width, 1.5 ; chela length, 7.0, width, 1.3, depth, 1.2; movable finger length, 4.9. (* Including telson length).

\section{Hottentotta Birula, 1908}

\section{Hottentotta mateui sp.n.}

Figs 50-56.

HOLOTYPE + . Chad, Ennedi Plateau, Biti Tehëc, N Bassé, 1,090 m, 12.IX.1958, leg. J. Mateu.

NAME. Honours J. Mateu, CNRS, who collected several of the new species described in this study.

DIAGNOSIS. Scorpions of small to moderate size in relation to the other congeners, with $\circ$ reaching 22 $\mathrm{mm}$ in total length. General coloration yellow to pale yellow with carapace and tergites infuscated. Carinae and granulations moderately marked on carapace, tergites and metasomal segments; intermediate carinae complete in metasomal segments I to III. Pectinal tooth count $22-23$ in + . Pedipalp fixed and movable fingers with 12 or 13 rows of granules.

RELATIONSHIPS. Hottentotta mateui sp.n. is most certainly associated with the Hottentotta minax group of species. It can, however, be distinguished from the other species of this group, in particular from Hottentotta acostai Lourenço, 2004, by the following characters: (i) smaller size; $22 \mathrm{~mm}$ in total length versus 50 mm for $H$. acostai, (ii) a very pale coloration with only the carapace and tergites infuscated, (iii) less marked granulations on carapace and tergites than in $H$. acostai, (iv) pectinal tooth counts in the new species reveal a larger number of teeth than those found in 90 of $H$. acostai; 22-23 versus 19-20.

DESCRIPTION. Coloration: Basically yellow to pale yellow. Prosoma: Carapace yellowish, with anterior and median zones strongly infuscated; eyes surrounded by black pigment. Mesosoma yellowish, with infuscated confluent zones. Metasomal segments I to V yellowish; latero-ventral and ventral carinae infuscated; telson yellowish; aculeus yellow at base and reddish at tip. Venter yellowish. Chelicerae yellowish, without variegated spots; fingers yellow with reddish teeth. Pedipalps yellow to pale yellow; chelal fingers with oblique rows of granules reddish. Legs pale yellow.

Carapace moderately granular; anterior margin with a median concavity; carinae weak to moderate; anterior median, central median and posterior median carinae moderately granular; furrows weak. Median ocular tubercle slightly anterior to centre of carapace; median eyes moderate, separated by 1.5 ocular diameters; three pairs of lateral eyes. Sternum triangular, slightly longer than wide. Mesosoma: Tergites moderately to weakly granular; three longitudinal carinae moderately crenulate on all tergites; tergite VII pentacarinate. Venter: Genital operculum divided longitudinally; each plate semi-oval in shape. Pectines: Pectinal tooth count 22-23 in holotype; middle basal lamella of pectines not dilated. Sternites smooth, with moderately elongated spiracles; four weakly marked carinae on sternite VII; other sternites without carinae, with only two weak furrows. Metasomal segments I to III with ten moderately to weakly crenulate carinae; IV with eight moderately crenulated carinae; segment $\mathrm{V}$ with five crenulate carinae; ventral aspect with two incomplete carinae in proximal half, parallel to ventral carinae; all segments with a smooth dorsal depression. Intercarinal spaces weakly granular to smooth. Telson smooth dorsally and granular latero-ventrally, with a moderately short and curved aculeus; subaculear tooth vestigial. Cheliceral dentition as defined by Vachon [1963] for Buthidae; movable finger with external distal tooth slightly shorter than internal distal tooth, basal teeth strongly reduced; ventral aspect of both finger and manus covered with setae. Pedipalp femur pentacarinate; patella with 7 or 8 weakly marked carinae; chela smooth, without carinae; tegument from moderately granular to smooth. Fixed and movable fingers with 12 or 13 oblique rows of granules; internal and external accessory granules present; distal extremity of movable fingers with four granules. Legs: Tarsus ventrally with two longitudinal rows of 5-7 spines. Tibial spurs present on legs III and IV; prolateral and retrolateral spurs present in all legs. Trichobothriotaxy: Trichobothrial pattern of type A, orthobothriotaxic as defined by Vachon [1974]. Dorsal trichobothria of femur arranged in $\beta$ configuration [Vachon, 1975].

Morphometric values (in $\mathrm{mm}$ ) of holotype. Total length, $22.1(25.2 *)$. Carapace: length, 3.0; anterior width, 2.2; posterior width, 3.2. Mesosoma length, 7.8. Metasomal segments. I: length, 1.6; width, 1.8; V: length, 3.1; width, 1.4; depth, 1.5. Telson length, 3.1. Vesicle: width, 1.2; depth, 1.1. Pedipalp: femur length, 2.5, width, 1.0; patella length, 2.9, width, 1.2; chela length, 4.9, width, 1.0, depth, 0.9; movable finger length, 3.2. (* Including telson length). 


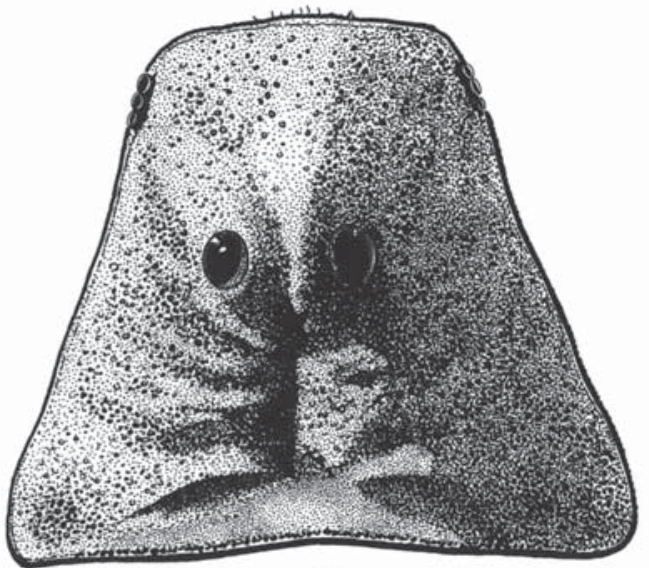

(8)

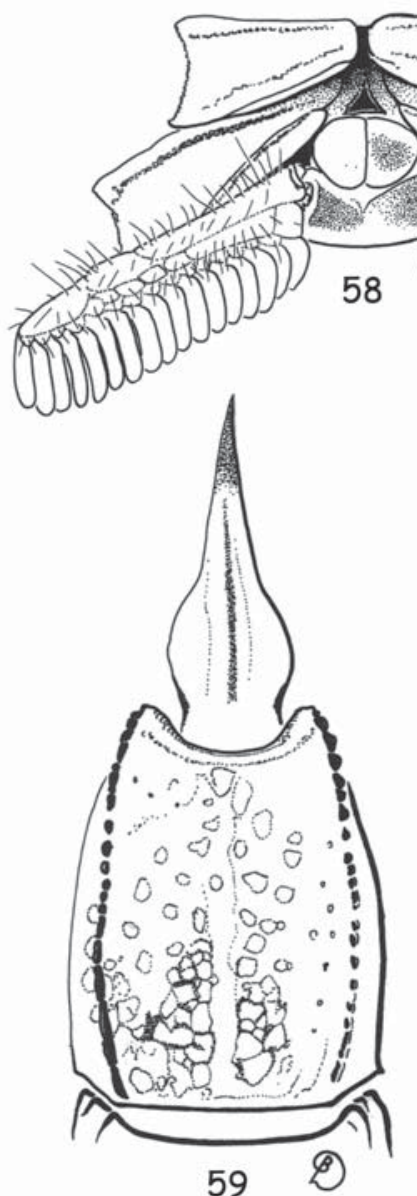

57
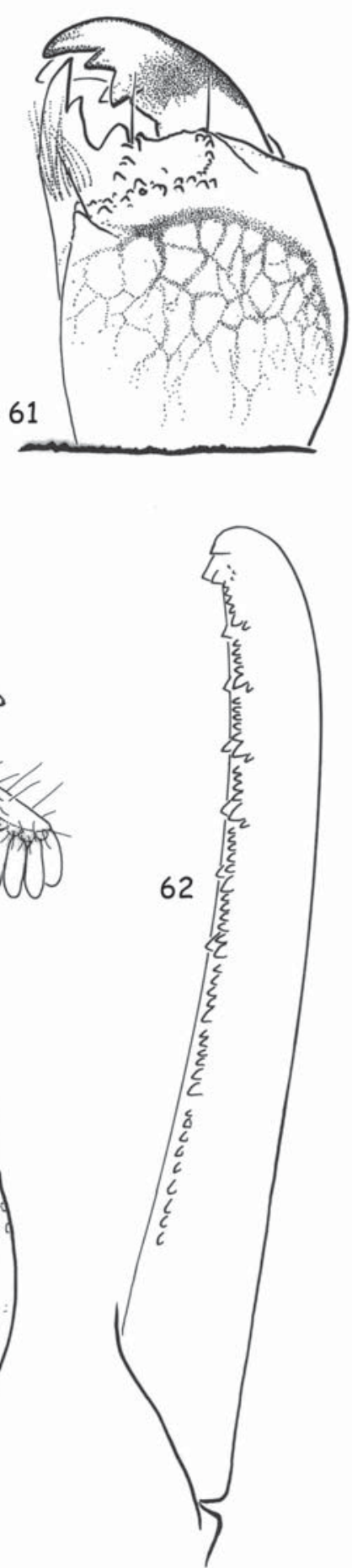

Figs 57-62. Orthochirus minor sp.n., holotype: 57 - carapace, dorsal aspect; 58 - coxapophysis, sternum, genital operculum and pectines; $59 \& 60$ - metasomal segment $\mathrm{V}$ and telson, ventral and lateral aspects; 61 - chelicera, dorsal aspect; 62 - cutting edge of movable finger with rows of granules.

Рис. 57-62. Orthochirus minor sp.n., голотип: 57 - карапакс, сверху; 58 - коксапофиз, стернит, крышечка гениталий и пектины; 59-60 - сегмент V метасомы и тельсон, соответственно снизу и сбоку; 61 - хелицера, сверху; 62 - режущий край подвижного пальца с рядами гранул. 

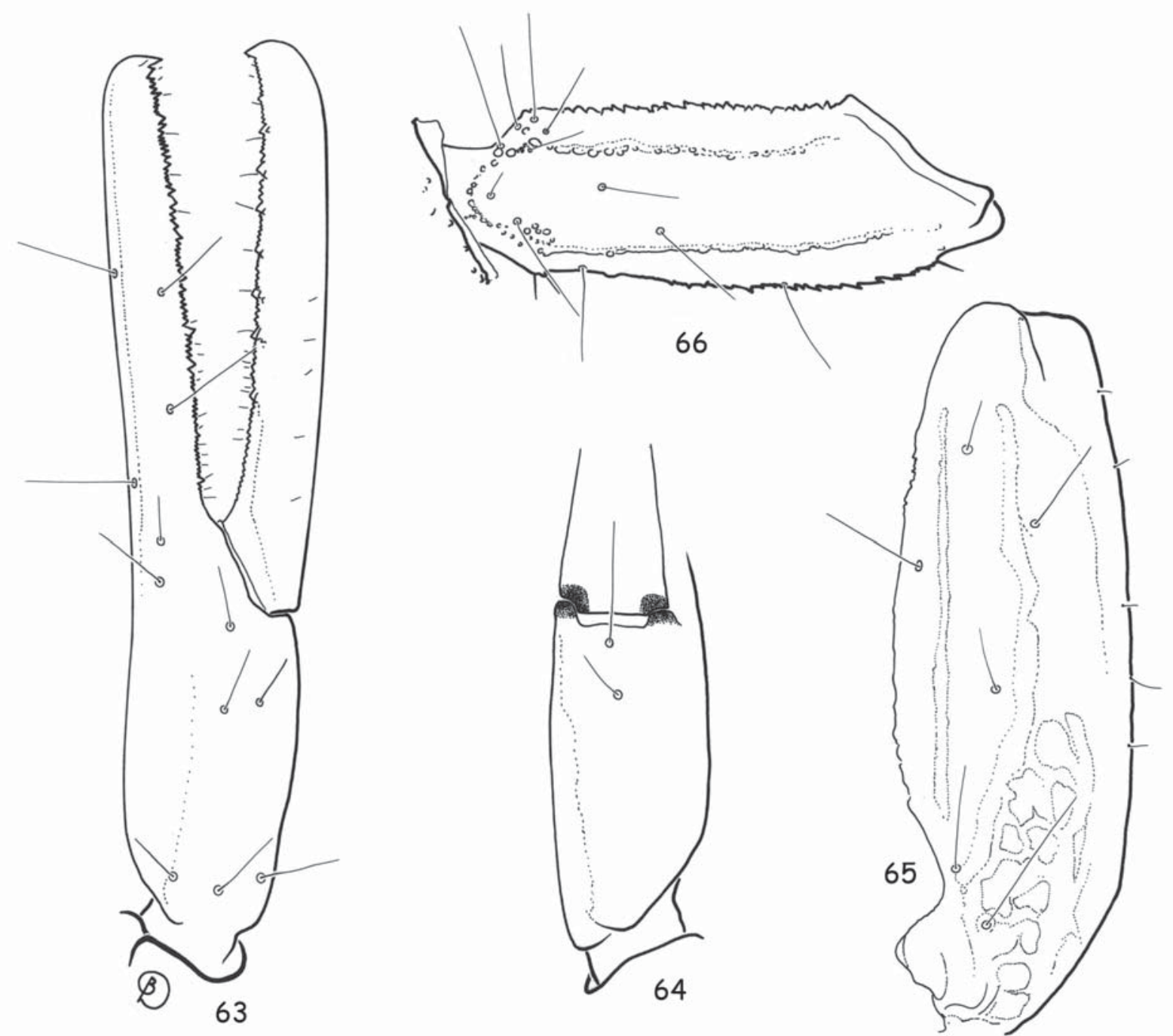

Figs 63-66. Orthochirus minor sp.n., holotype, trichobothrial pattern: $63 \& 64-$ chela, dorso-external and ventral aspects, respectively; 65 - patella, dorsal aspect; 66 - femur, dorsal aspect.

Рис. 63-66. Orthochirus minor sp.n., голотип, распределение трихоботрий: 63 и 64 - хела, соответственно снаружи и сверху и снизу; 65 - пателла, сверху; 66 - бедро, сверху.

Orthochirus Karsch, 1891

Orthochirus minor sp.n.

Figs 57-66.

HOLOTYPE O', Chad, Ennedi, N'Goro, under a rock, 29.X.1958, leg. J. Mateu.

NAME. The specific name refers to the small size of the new species.

DIAGNOSIS. Small-sized scorpions as compared to the other known congeners, reaching a total length of $18.9 \mathrm{~mm}$ in $\sigma^{7}$. General coloration reddish-yellow. Anterior margin of carapace weakly convex, almost straight. Ventral aspect of metasomal segment V without granulations posteriorly. Fixed and movable fingers of pedipalps with $8-8$ rows of granules; accessory granules present next to all six distal rows. Pectines with 17-17 teeth in $\sigma^{7}$. Trichobothriotaxy: A- $\beta$-neobothriotaxy-minorante.

RELATIONSHIPS. Orthochirus minor sp.n. can be distinguished from the other African species of Orthochirus, in particular from O. innesi Simon, 1910 and $O$. tassili Lourenço et Leguin, 2011, by the following characters: (i) smaller size, (ii) a distinct and much paler pigmentation pattern, (iii) only $8-8$ rows of granules on chela fingers, (iv) ventral aspect of metasomal segment V without granulations.

DESCRIPTION. Coloration: Basically reddish-yellow with some darker zones. Prosoma: Carapace reddish-yellow with darker zones laterally and posteriorly; median and lateral eyes surrounded by black pigment. Mesosoma reddish-yellow; carinae and granulations reddish. Metasomal segments reddish with darker zones in ventral aspect; telson reddish-yellow; aculeus 
yellowish at base and reddish at tip. Metasomal carinae marked with blackish. Venter yellowish to reddishyellow; two triangular pale zones on $\sigma^{7}$ sternites $\mathrm{V}$ and VI; pectines pale yellow. Chelicerae yellowish, with some dark variegated spots anteriorly; fingers reddish. Pedipalp femur and patella brownish-yellow; chela yellowish; fingers with oblique rows of granules reddish. Legs yellowish slightly infuscated.

Carapace with thin, but intense granulations; anterior margin with a weak convexity, almost straight. Carinae and furrows weakly marked. Median ocular tubercle slightly anterior to centre of carapace; median eyes separated by more than one ocular diameter. Three pairs of lateral eyes. Sternum subtriangular to subpentagonal, wider than long. Mesosoma: Tergites with thin, but intense granulations; median carina moderate to weak on all tergites. Tergite VII pentacarinate with strong carinae. Venter: Genital operculum small, weakly elongated, divided longitudinally into two suboval plates. Pectines: Pectinal tooth count $17-17$ in holotype; basal middle lamellae of each pecten not dilated. Sternites almost smooth, with small slit-like spiracles; VII with four carinae, moderately to weakly marked, and some minute granulations. Metasoma: Segments rounded, with carinae moderately marked; granulations weakly marked, almost smooth; segments I to III with ten carinae; segments IV and V with punctations; ventral aspect of segment $\mathrm{V}$ without granulations in distal region. Intercarinal spaces smooth dorsally, weakly granular both laterally and ventrally. Telson smooth; aculeus longer than vesicle and moderately curved; subaculear tooth absent. Cheliceral dentition characteristic of Buthidae [Vachon, 1963]; movable finger with weakly marked basal teeth; ventral aspect of both finger and manus with thin setae. Pedipalps: Femur with five moderate carinae, granular; patella with seven weakly marked carinae; chela without carinae, smooth. Fixed and movable fingers with $8-8$ rows of granules. Trichobothriotaxy: A- $\beta$; neobothriotaxy-minorante [Vachon, 1974, 1975]. Legs: Tarsus with two rows of setae ventrally. Tibial spurs reduced; pedal spurs moderately to weakly marked.

Morphometric values (in $\mathrm{mm}$ ) in holotype. Total length, $18.9\left(21.5^{*}\right)$. Carapace: length, 2.5; anterior width, 1.8; posterior width, 3.1. Mesosoma length, 5.5. Metasomal segments. I: length, 1.5; width, 2.1; V: length, 2.8; width, 2.3; depth, 1.7. Telson length, 2.6. Vesicle: width, 0.9; depth, 0.8. Pedipalp: femur length, 1.9 , width, 0.6 ; patella length, 2.3 , width, 0.8 ; chela length, 3.3, width, 0.6 , depth, 0.6 ; movable finger length, 2.1. (* Including telson length).

\section{Orthochirus tibesti sp.n.}

Figs 67-76.

HOLOTYPE O ${ }^{7}$, Chad, Tibesti, IX.1977, leg. P.M. Brignoli. PARATYPES: $2 \sigma^{7} \sigma^{7}, 1+$, same locality, together with holotype.

NAME. The specific name is a noun in apposition and refers to the type locality.
DIAGNOSIS. Medium to large-sized scorpions in relation to the other congeners, reaching a total length of $27.7 \mathrm{~mm}$ in $\mathrm{O}^{7}$ and $34.0 \mathrm{~mm}$ in 9 . General coloration yellow to reddish-yellow. Anterior margin of carapace moderately to strongly convex; carinae and granulations strongly marked. Ventral aspect of metasomal segment $\mathrm{V}$ with a few granulations posteriorly. Fixed and movable fingers of pedipalps with 9-9 rows of granules; accessory granules present on the seven distal rows. Pectines with 17 to 19 teeth in $\sigma^{7} \sigma^{7}$ and 1517 teeth in + . Trichobothriotaxy: A- $\beta$ neobothriotaxyminorante.

RELATIONSHIPS. Orthochirus tibesti sp.n. can be distinguished from the other congeners, in particular from O. innesi Simon, 1910 and O. tassili Lourenço et Leguin, 2011, by the following characters: (i) larger size, (ii) a distinct pigmentation pattern; much paler, (iii) a small, moderately elongated, oval to rounded genital operculum in + , (iv) ventral aspect of metasomal segment $\mathrm{V}$ with a few granulations, (v) anterior edge of carapace strongly convex, (vi) carapace carinae and granulation strongly marked.

DESCRIPTION. Coloration: Basically yellow to reddish-yellow. Prosoma: Carapace reddish-yellow with some infuscated zones; median and lateral eyes surrounded by black pigment. Mesosoma reddish-yellow; carinae and granulations dark reddish. Metasomal segments reddish-brown; telson reddish-yellow, aculeus reddish. Metasomal carinae dark, almost blackish. Venter yellowish; two triangular pale zones on sternites V and VI of $O^{7}$; pectines pale yellow. Chelicerae yellowish, with some vestigial variegated spots; fingers reddish. Pedipalps, femur and patella yellowish with some infuscated zones; chela yellow; fingers with oblique rows of granules reddish. Legs yellow to pale yellow.

Carapace moderately to strongly granular; anterior margin with a moderate to strong convexity. Carinae and furrows moderately marked. Median ocular tubercle slightly anterior to centre of carapace; median eyes separated by more than one ocular diameter. Three pairs of lateral eyes. Sternum subtriangular to subpentagonal, wider than long. Mesosoma: Tergites with a moderately to strongly marked granulation; median carina moderate on all tergites. Tergite VII pentacarinate with strong carinae. Venter: Genital operculum moderate to small, moderately to weakly elongated, divided longitudinally into two suboval to round plates. Pectines: Pectinal tooth count 18-19 in $\sigma^{7}$ holotype, 17-17 or 19-19 in $\sigma^{7}$ paratypes, $15-17$ in 9 paratype; basal middle lamellae of each pecten not dilated. Sternites weakly granular, with small slit-like spiracles; VII with four moderate carinae and some granulations. Metasomal segments rounded, with carinae moderately to strongly marked; granulations moderately developed; segments I to III with ten carinae; segments IV and V with punctations; ventral aspect of segment $\mathrm{V}$ with some granulations in distal region. Intercarinal spaces weakly granular dorsally; moderately granular laterally and ventrally. Telson smooth; aculeus longer than vesicle and moderately curved; subaculear tooth absent. 

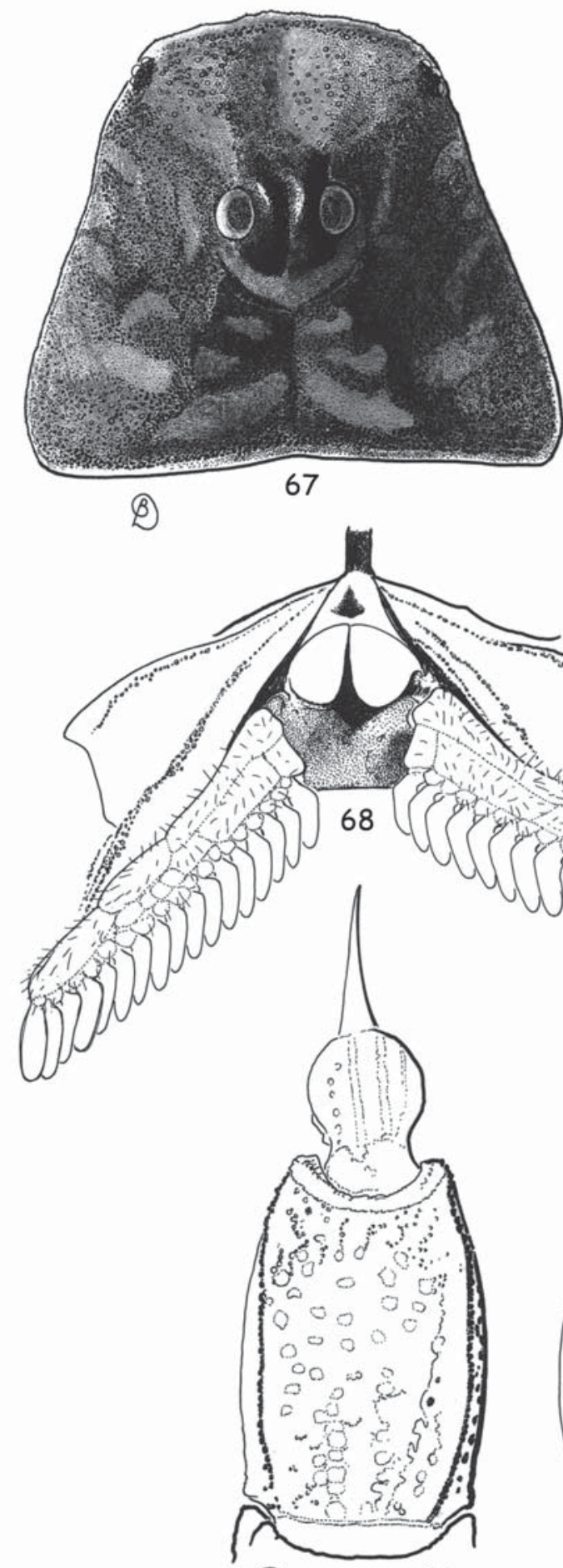

(8)

69

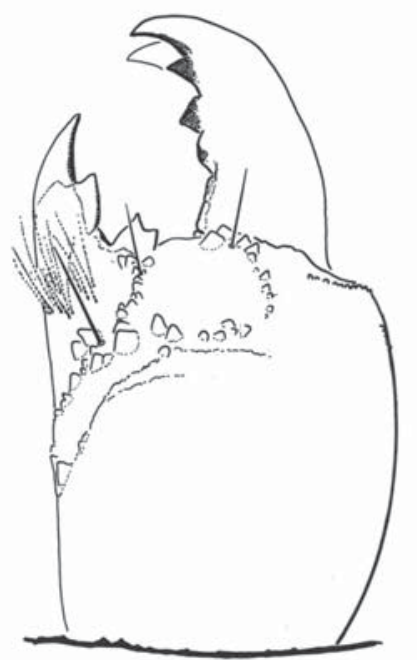

71

i.
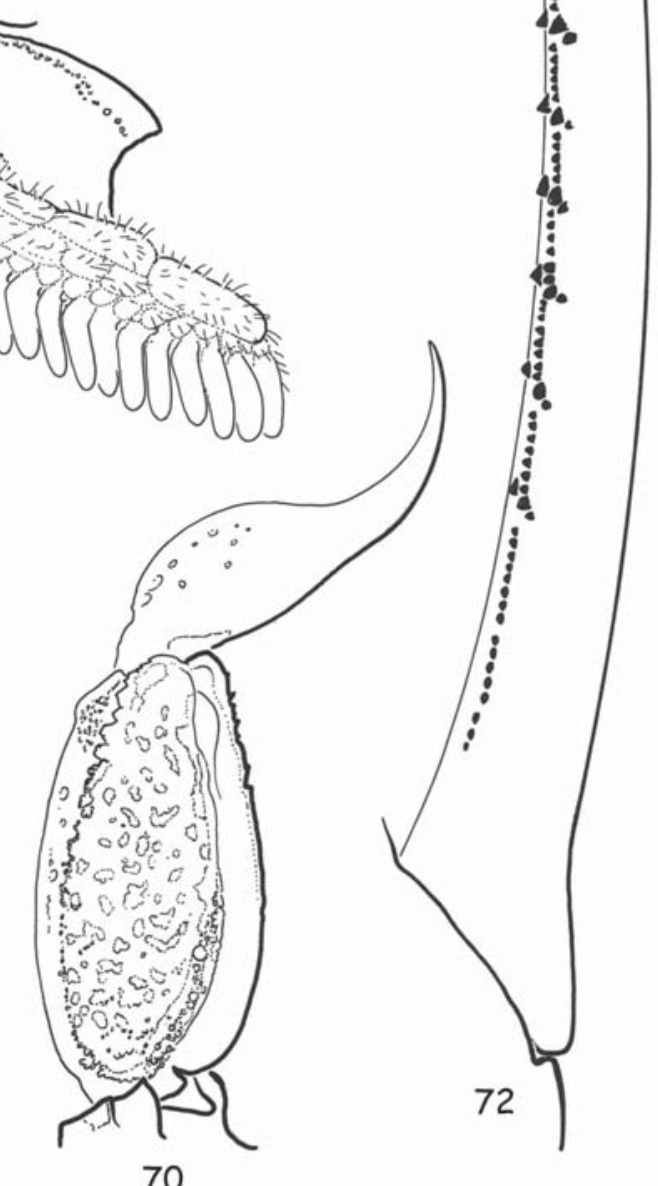

Figs 67-72. Orthochirus tibesti sp.n., holotype: 67 - carapace, dorsal aspect; 68 - coxapophysis, sternum, genital operculum and pectines; 69 \& 70 - metasomal segment $\mathrm{V}$ and telson, ventral and lateral aspects, respectively; 71 - chelicera, dorsal aspect; 72 cutting edge of movable finger with rows of granules.

Рис. 67-72. Orthochirus tibesti sp.n., голотип: 67 - карапакс, сверху; 68 - коксапофиз, стернит, крышечка гениталий и пектины; 69-70 - сегмент V метасомы и тельсон, соответственно снизу и сбоку; 71 - хелицера, сверху; 72 - режущий край подвижного пальца с рядами гранул. 


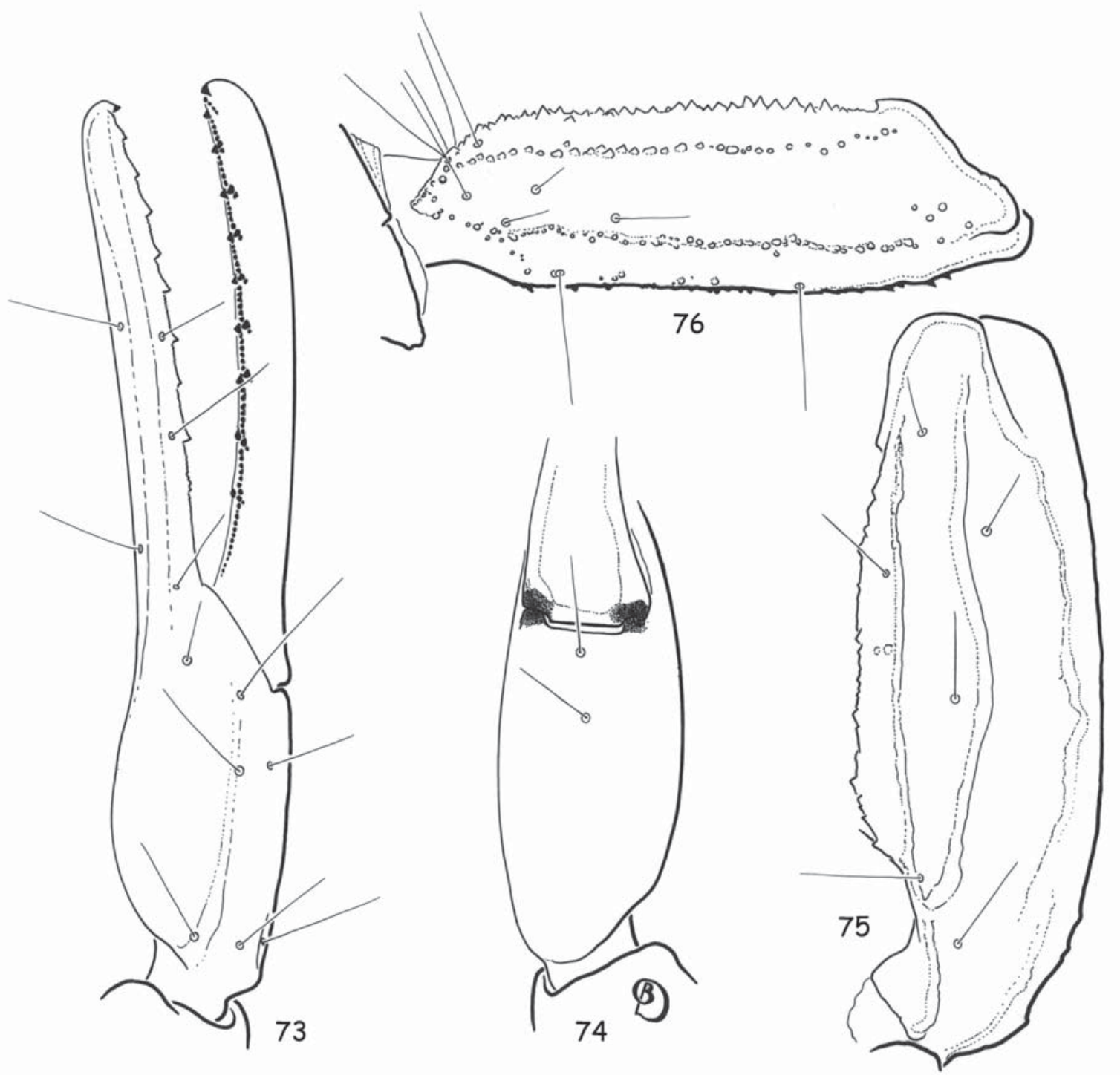

Figs 73-76. Orthochirus tibesti sp.n., holotype, trichobothrial pattern: $73 \& 74-$ chela, dorso-external and ventral aspects, respectively; 75 - patella, dorsal aspect; 76 - femur, dorsal aspect.

Рис. 73-76. Orthochirus tibesti sp.n., голотип, распределение трихоботрий: 73-74-хела, соответственно снаружи и сверху и снизу; 75 - пателла, сверху; 76 - бедро, сверху.

Cheliceral dentition characteristic of the family Buthidae [Vachon, 1963]; movable finger with reduced and fused basal teeth; ventral aspect of both finger and manus with thin setae. Pedipalps: Femur with five moderate carinae, granular; patella with 6 or 7 weakly marked carinae, not granular; chela without carinae, smooth. Fixed and movable fingers with 9-9 rows of granules; accessory granules present on all seven distal rows. Trichobothriotaxy: A- $\beta$ neobothriotaxy-minorante [Vachon, 1974, 1975]. Legs: Tarsus with two rows of setae ventrally. Tibial spur reduced on legs III and IV; pedal spurs moderately marked on all legs.

Morphometric values (in $\mathrm{mm}$ ) of $\sigma^{7}$ holotype. Total length, $27.7\left(31.4^{*}\right)$. Carapace: length, 3.5; anterior width, 2.4; posterior width, 4.2. Mesosoma length, 7.9. Metasomal segments. I: length, 2.2; width, 2.7; V: length, 4.5; width, 2.8; depth, 2.1. Telson length, 3.7. Vesicle: width, 1.3; depth, 1.2. Pedipalp: femur length, 3.0, width, 0.9; patella length, 3.5, width, 1.2; chela length, 4.7 , width, 0.9 , depth, 0.9 ; movable finger length, 3.3. (* Including telson length).

Scorpionidae Latreille, 1802

Scorpio Linnaeus, 1758

Scorpio ennedi sp.n.

Figs 77-87.

HOLOTYPE $q$, Chad, Ennedi, Ovedi Sala, Merktcha-Septz, 9.VIII.1958, leg. J. Mateu.

NAME. The specific name is a noun in apposition and refers to the type locality. 

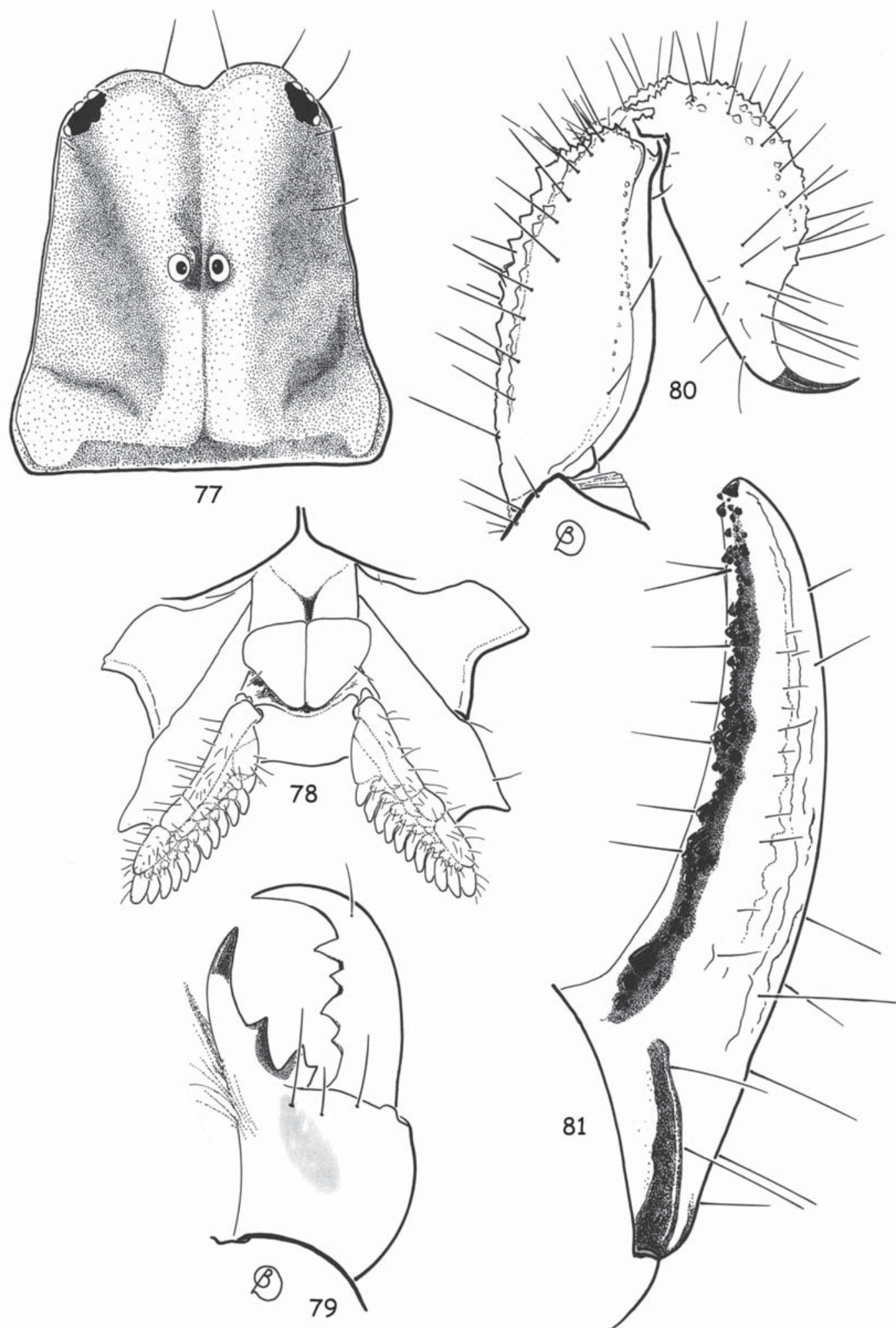

Figs 77-81. Scorpio ennedi sp.n., holotype: 77 - carapace, dorsal aspect; 78 - coxapophysis, sternum, genital operculum and pectines; 79 - chelicera, dorsal aspect; 80 - metasomal segment V and telson, lateral aspect; 81 — cutting edge of movable finger with rows of granules.

Рис. 77-81. Scorpio ennedi sp.n., голотип: 77 - карапакс, сверху; 78 - коксапофиз, стернит, крышечка гениталий и пектины; 79 - хелицера, сверху; 80 - сегмент V метасомы и тельсон, сбоку; 81 - режущий край подвижного пальца с рядами гранул. 

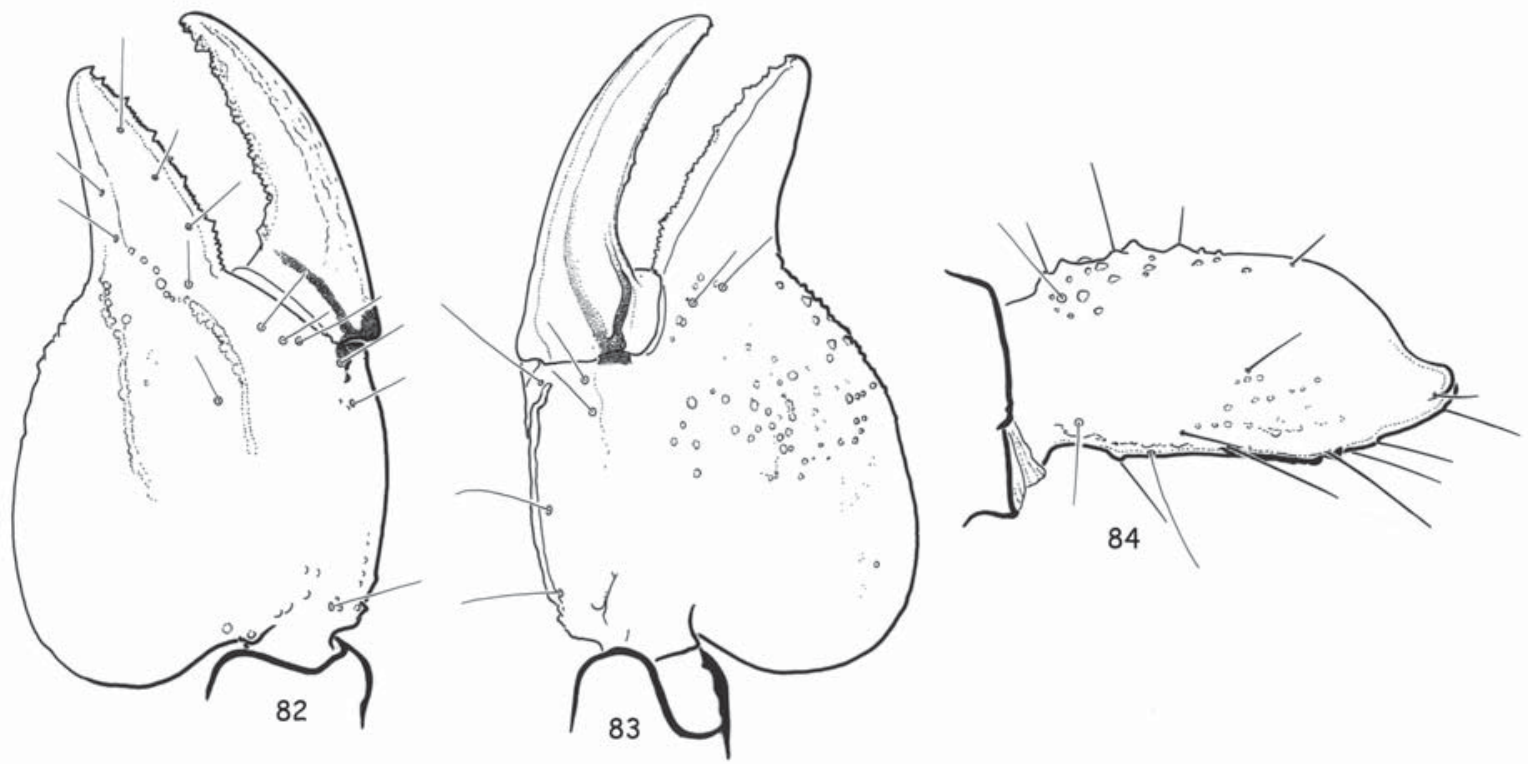

Figs 82-84. Scorpio ennedi sp.n., holotype, trichobothrial pattern: $82 \& 83$ - chela, dorso-external and ventro-internal aspects, respectively; 84 - femur, dorsal aspect.

Рис. 82-84. Scorpio ennedi sp.n., голотип, распределение трихоботрий: 82-83 - хела, соответственно снаружи и сверху, а также снизу и изнутри; $84-$ бедро, сверху.

DIAGNOSIS. Scorpions of small size as opposed to the other congeners, $O$ reaching $40.2 \mathrm{~mm}$ in total length. Coloration basically yellow to pale yellow, with some infuscated zones on carapace and tergites; pedipalps, legs, chelicerae and telson paler than body. Pedipalps, especially chela, almost acarinate; dorsal and dorso-external carinae absent. Chelal manus with weakly marked granules in dorso-external aspect. Telson moderately bulbous, with spinoid granules ventrally. Pectines narrowed, with 11-11 teeth. Trichobothriotaxy of type C, orthobothriotaxic. Genital operculum with a cordiform plate in $P$.

RELATIONSHIPS. Scorpio ennedi sp.n. can be distinguished from the other Scorpio species, in particular from S. sudanensis Lourenço et Cloudsley-Thompson, 2009, geographically the closest congener [Lourenço, 2009; Lourenço \& Cloudsley-Thompson, 2009], by the following combination of features: (i) paler overall coloration, (ii) pedipalp chela almost acarinated; dorsal and dorso-external carinae absent; chelal manus with moderately marked granules, (iii) telson slightly bulbous, with ventral spinoid granules, (iv) pectines with 11-11 teeth; + + of $S$. sudanensis should have only 6 or 7 teeth.

DESCRIPTION. Coloration: Body basically yellow to pale yellow. Prosoma: Carapace yellow with some infuscated zones. Mesosoma: Tergites yellow like carapace, with some infuscated zones; sternites yellowish. Coxapophysis, sternum, genital operculum and pectines yellow. Metasoma with all segments yellow. Telson yellow; aculeus reddish-yellow at base and dark reddish at extremity. Chelicerae yellowish, slightly in- fuscated; fingers yellowish with reddish teeth. Pedipalps: Femur, patella and chela yellowish; fingers reddish; dentate margins of fingers dark, almost blackish. Legs pale yellow.

Carapace acarinate, without granulations, smooth, lustrous; anterior margin with a moderately pronounced concavity; posterior furrows strongly developed; median ocular tubercle distinct in centre of carapace; three pairs of lateral eyes of equal size. Mesosoma: Tergites acarinate and smooth, lustrous, without granulations. Sternum pentagonal, wider than long. Venter: Genital operculum formed by one heart-shaped plate in + . Pectines narrowed; pectinal tooth count 11-11; fulcra moderately developed. Sternites smooth and shining, with two longitudinal parallel furrows on III to VI; VII with four weakly marked carinae; spiracles linear and moderate. Metasoma with moderately marked carinae in segments I to IV; granulation becoming spiniform in segment V; ventral and latero-ventral carinae intensely spinoid in V; all intercarinal surfaces weakly granular, almost smooth. Telson moderately bulbous, with spinoid granules ventrally, forming four ventral carinae; aculeus shorter than vesicle and moderately curved; all segments and telson with a strongly marked setation. Cheliceral dentition characteristic of the Scorpionidae [Vachon, 1963]; movable finger with one subdistal tooth and inconspicuous basal teeth. Pedipalps with weak granulation, almost smooth; femur with four, almost complete carinae; patella with dorsal carina almost complete; chela with weakly marked ventral carinae; other carinae absent; dorso-external aspect of manus weakly granular. Dentate margin of fixed and 

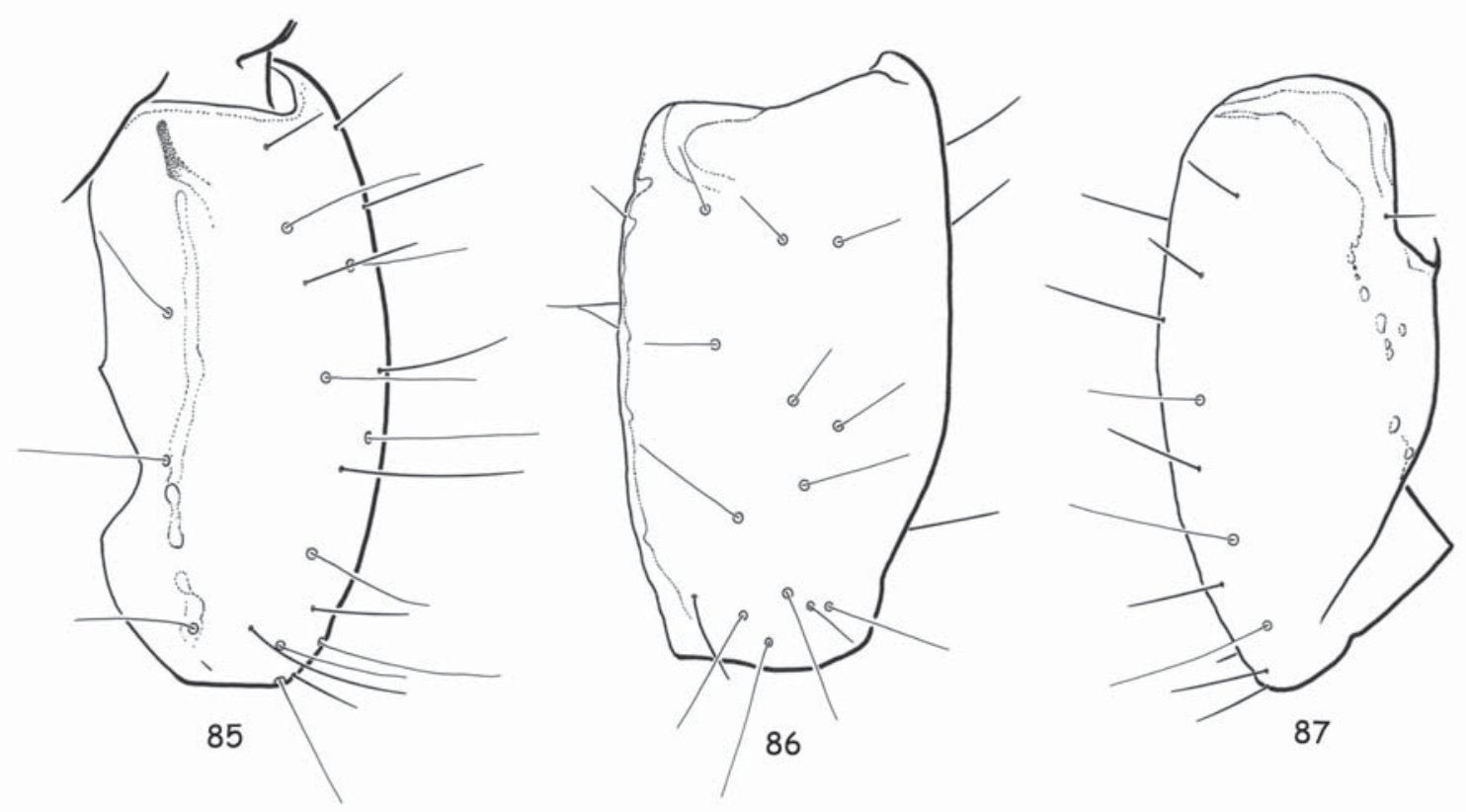

Figs 85-87. Scorpio ennedi sp.n., holotype, patella, dorsal, external and ventral aspects, respectively.

Pис. 85-87. Scorpio ennedi sp.n., голотип, пателла, соответственно сверху, снаружи и снизу.

movable fingers with a series of granules divided by 4 or 5 strong accessory granules. Trichobothriotaxy of type C; orthobothriotaxic [Vachon, 1974]; femur with three trichobothria, patella with 19, chela with 26 ones. Legs: Tarsi I to IV with 5/8-4/7:6/8-6/8:7/9-7/9:6/9$6 / 9$ internal and external spines arranged in series.

Morphometric values (in $\mathrm{mm}$ ) of holotype. Total length, $40.2\left(44.4^{*}\right)$. Carapace: length, 6.5; anterior width, 4.2; posterior width, 6.4. Mesosoma length, 18.0. Metasomal segments. I: length, 2.3; width, 3.2; V: length, 4.4; width, 2.2; depth, 1.9. Telson length, 4.2. Vesicle: width, 2.1; depth, 1.8. Pedipalp: femur length, 3.8, width, 2.0; patella length, 4.1, width, 2.3; chela length, 8.5 , width, 2.8 , depth, 5.2; movable finger length, 4.6. (* Including telson length).

\section{Biogeographical comments}

Furon [1951] suggested that both flora and fauna currently supported by the Sahara may well be very old. Their present patterns of distribution reflects not only the consequences of palaeogeographic factors, but is also largely the result of various palaeoclimates. These palaeoclimatic events might have had important impacts during the Quaternary when Europe (and North America) faced periods of glaciation. During these, Africa experienced periods of intense rain and, additionally, an increase in the amount of ice on the mountains (particularly in eastern Africa). The last rather humid period in the Sahara was very recently, only some 3,000 years BP.
In fact the present composition of the Saharan fauna is the heritage of ancient faunas present in North Africa since the beginning of or, at most, middle Cenozoic times [Vachon, 1952]. North Africa has experienced numerous palaeoclimatological vicissitudes in the past few million years, some even in more or less recent Quaternary times. The Sahara has undergone a series of wet periods, the most recent occurring 10,000 5,000 years BP, and it was not until about 3,000 years BP that the Sahara assumed its present arid state [Cloudsley-Thompson, 1971, 1974, 1984]. Even though recent studies suggest that the Sahara Desert may be much older than thought previously [Schuster et al., 2006], it seems reasonable to surmise that extremely arid areas have always existed as patchy desert enclaves, even when the general climate of North Africa enjoyed more mesic conditions. In these desert regions, a specialized scorpion fauna could have evolved. In contrast, other lineages less well adapted to drought, and previously present only in mesic environments, have regressed markedly in their distribution. They have therefore experienced negative selection and could be on the road to extinction, unless rescued by climatic change. In other cases, populations have been reduced to very limited and patchy zones, sometimes with remarkable disjunctions in their distribution patterns.

These 'ancient lineages' adapted to arid conditions most certainly have phylogenetic relations to extant groups such as the genera Androctonus Ehrenberg, Buthacus, Buthiscus Birula, 1905, Buthus and Leiurus Ehrenberg, 1828, some of which are typically psam- 


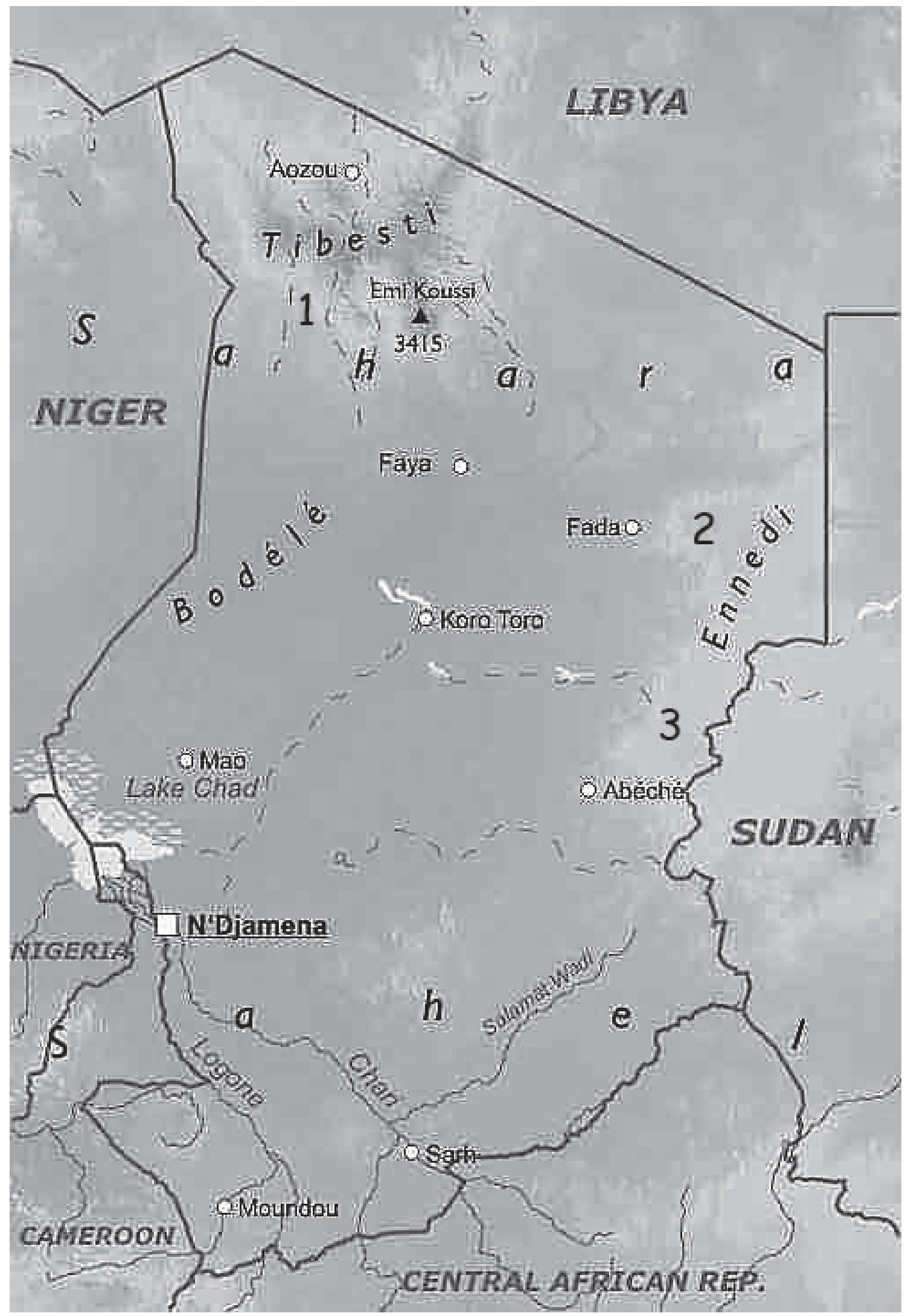

Fig. 88. Physical map of Chad, showing the locations of Tibesti (1), Ennedi (2) and Kapka (3).

Рис. 88. Физическая карта Чада с указанием мест находок в Тибести (1), Эннеди (2) и Капка (3). 


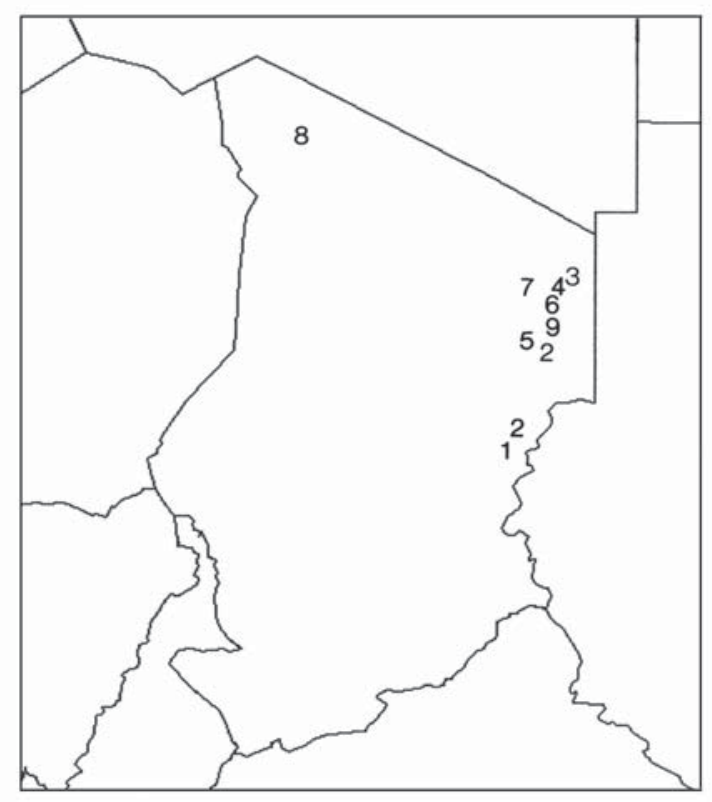

Fig. 89. Map of Chad with the type localities of the new species: 1 - Androctonus pallidus sp.n.; 2 - Buthacus golovatchi sp.n.; 3 - Butheoloides (s.str.) granulatus sp.n.; 4 - Buthus hassanini sp.n.; 5 - Compsobuthus boucheti sp.n.; 6-Hottentotta mateui sp.n.; 7 - Orthochirus minor sp.n.; 8 - Orthochirus tibesti sp.n.; 9 - Scorpio ennedi sp.n.

Рис. 89. Карта Чада с указанием типовых мест находок новых видов: 1 - Androctonus pallidus sp.n.; 2 - Buthacus golovatchi sp.n.; 3 - Butheoloides (s.str.) granulatus sp.n.; 4 Buthus hassanini sp.n.; 5 - Compsobuthus boucheti sp.n.; 6 Hottentotta mateui sp.n. 7 - Orthochirus minor sp.n.; 8 Orthochirus tibesti sp.n.; 9 - Scorpio ennedi sp.n.

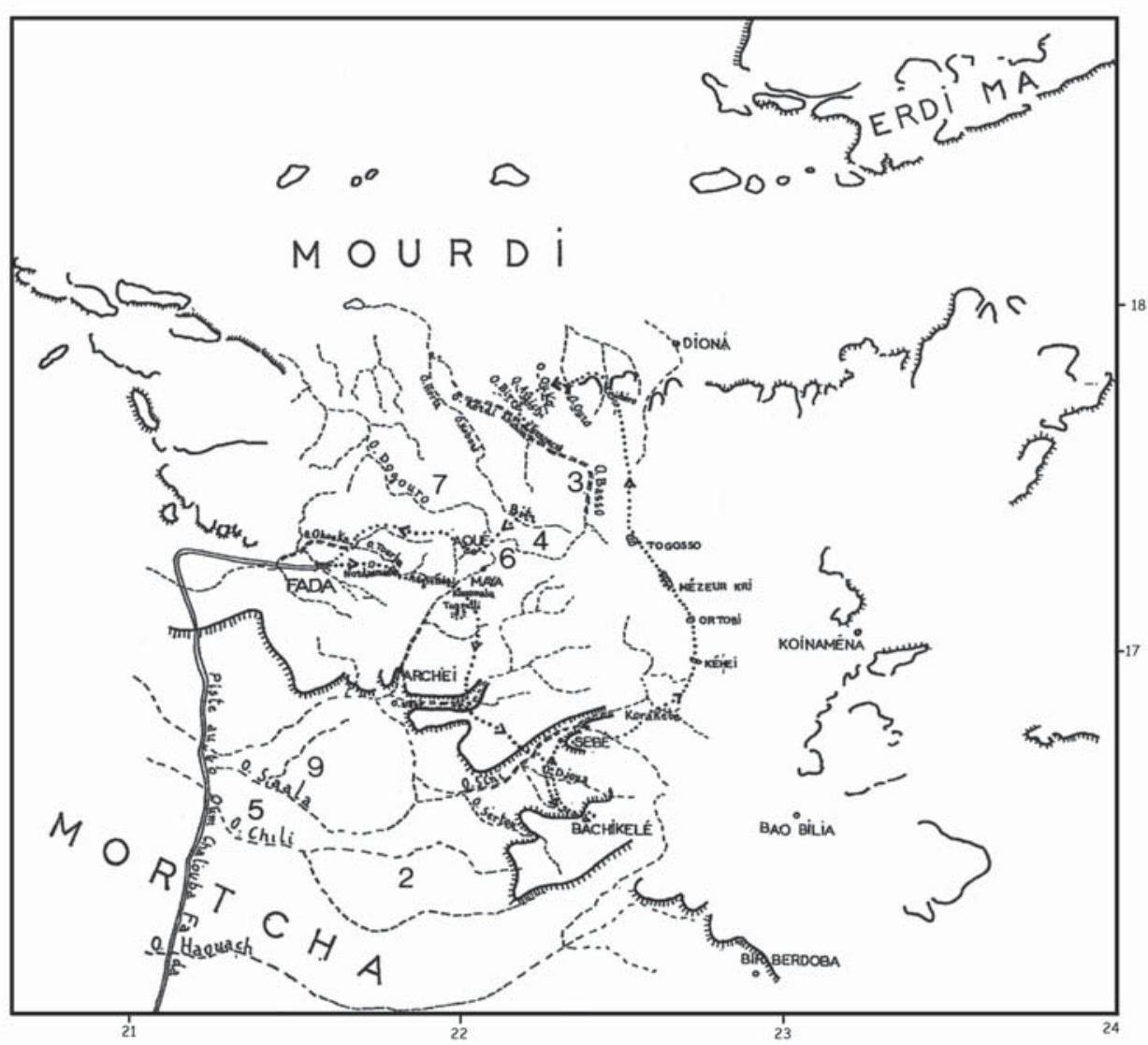

Fig. 90. Map of the Ennedi region with the type localities of the new species from this site: 2 - Buthacus golovatchi sp.n.; 3 Butheoloides (s. str.) granulatus sp.n.; 4 - Buthus hassanini sp.n. 5 - Compsobuthus boucheti sp.n.; 6 - Hottentotta mateui sp.n.; 7 Orthochirus minor sp.n.; 9 - Scorpio ennedi sp.n.

Рис. 90. Карта района Эннеди с указанием типовых мест находок оттуда: 2 - Buthacus golovatchi sp.n.; 3 - Butheoloides (s.str.) granulatus sp.n.; 4 - Buthus hassanini sp.n.; 5 - Compsobuthus boucheti sp.n.; 6 - Hottentotta mateui sp.n.; 7 - Orthochirus minor sp.n.; 9 - Scorpio ennedi sp.n. 
mophilic. It is noteworthy that these lineages must have been present in North Africa for at least 10 to $15 \mathrm{My}$ [Gantenbein \& Largiadèr, 2003; Lourenço \& Vachon, 2004]. In contrast, other lineages less well adapted to aridity and previously only present in more mesic environments have regressed markedly in their distribution with the expansion of the desert.

The patterns observed today in the distribution of North African scorpions can be summarized as follows. The core Saharan region, defined by Vachon [1952] as the 'central compartment', in which only the groups are distributed the best adapted to xeric conditions, such as the genera Androctonus, Buthacus, Buthiscus, Buthus and Leiurus. A peri-Saharan zone of distribution forms an almost complete ring around the most arid core region of the Sahara. In this zone, some genera can be observed, such as Butheoloides, whose distribution follows a circle from the North of Algeria, through the Atlas mountains of Morocco, to the South via Senegal, and then to the East through Mali, Côte d'Ivoire, Nigeria, Sudan and Ethiopia [Lourenço, 2002, 2010 b]. Even more remarkable is the disjunction shown by the distribution of the genus Microbuthus, with some species in Mauritania and Morocco in western Africa, several other species in Eritrea, Djibouti and Egypt in eastern Africa, and finally some in Oman [Lourenço \& Duhem, 2007; Lowe, 2010].

Vachon [1951, 1952] drew attention to these extremely localized distributions of species and defined them as 'disrupted and limited territories'. Vachon also attempted to explain the observed patterns and made reference to Braestrup [1947] who had suggested a mechanism for exchanges through the Sahara Desert. According to these assumptions, Southern elements (Ethiopian) were able to reach the Northern regions, and Northern elements (Palaearctic) were able to disperse to the Southern regions of the Sahara. This hypothesis is valid for dynamic elements with a marked capacity for dispersion. Scorpion populations are, in many cases, predictable and stable. They show a weak capacity of readaptation to new environments. The present patterns of distribution of several groups of scorpions, in particular those showing important disjunctions, reflect rather large ranges of distribution in the past. The distinct palaeoclimatic vicissitudes experienced by the Sahara have presented an important selective factor over its scorpion populations. The reaction of these to abiotic factors was certainly varied depending on their own ecological strategies [Polis, 1990; Lourenço, 1991]. In some cases, the populations showed significant regressions in their distributions, and some populations may well have totally vanished. These regressions led to marked disruptions in geographic distributions and resulted in their present patchy patterns. As suggested by Vachon [1952], several groups less well adapted to xeric environments have their populations restricted to refugia. These can be represented in some oases, in particular in the Saharan massifs. Endemic genera, such as Cicileus Vachon, 1948, Lis- sothus Vachon, 1948, Egyptobuthus Lourenço, 1999 and Pseudolissothus Lourenço, 2001, provide useful examples [Vachon, 1952; Lourenço, 1999a, b, 2001]. In contrast, the presence in mesic environments of species belonging to groups associated with 'ancient lineages' well adapted to arid conditions, suggests a secondary readaptation. This could explain the occurrence of endemic species of Androctonus, Buthacus, Buthus, Compsobuthus, Hottentotta, Orthochirus and Scorpio in the Saharan massifs.

ACKNOWLEDGEMENTS. We are most grateful to Sergei Golovach, Russian Academy of Sciences, Moscow for his help in the publication of this paper, and to EliseAnne Leguin, MNHN, Paris for the preparation of the plates.

\section{References}

Braestrup F.W. 1947. Remarks on faunal exchange through the Sahara // Videnskabelige Meddeleiser fra Dansk Naturhistorisk Forening i Köbenhavn. T.110. P.1-15.

Cloudsley-Thompson J.L. 1966. The fauna of Jebel Marra, Western Sudan // Turtox News. Vol.44. No.9. P.218-220.

Cloudsley-Thompson J.L. 1967. Altitude and faunal distribution on Jebel Marra // Sudan Notes and Records. Vol.48. P.133-140.

Cloudsley-Thompson J.L. 1971. Recent expansion of the Sahara // International Journal of Environmental Studies. Vol.2. P.35-39.

Cloudsley-Thompson J.L. 1974. The expanding Sahara// Environmental Conservation. Vol.1. No.1. P.5-13.

Cloudsley-Thompson J.L. (ed.). 1984. Key Environments: Sahara Desert // Pergamon Press, Oxford: 348 pp.

Furon R. 1951. Les grandes lignes de la paléogéographie de la Berbérie et du Sahara; leur sens biogéographique // Compte Rendus Sommaires des Séances de la Société de Biogéographie. T.241. P.46-48.

Gantenbein B., Largiadèr C.R. 2003. The phylogeographic importance of the Strait of Gibraltar as a gene flow barrier in terrestrial arthropods: A case study with the scorpion Buthus occitanus as model organism // Molecular Phylogenetics and Evolution. Vol.28. No.1. P.119-130.

Gillet H. 1959. Une mission scientifique dans 1'Ennedi (NordTchad) et en Oubangui // Journal d'Agriculture tropicale et de Botanique appliquée. T.6. Fasc.11. P.505-573.

Gourgaud A., Vincent P.M. 2004. Petrology of two continental alkaline intraplate series at Emi Koussi volcano, Tibesti, Chad // Journal of Volcanology and Geothermal Research. Vol.129. No.4. P.261-290.

Happold D.C.D. 1969. The mammalian fauna of some jebels in the northern Sudan // The Journal of Zoology, London. Vol.157. No.2. P.133-145.

Hjelle J.T. 1990. Anatomy and morphology // Polis G.A. (Ed.), The Biology of Scorpions. Stanford: Stanford University Press. P.9-63.

Lourenço W.R. 1991. Biogéographie évolutive, écologie et les stratégies biodémographiques chez les scorpions néotropicaux // Compte Rendus de la Société de Biogéographie. T.67. Fasc.4. P.171-190.

Lourenço W.R. 1998. Uroplectoides abyssinicus gen. n., sp.n., a new genus and new species of scorpion (Scorpiones, Buthidae) from Ethiopia // Entomologische Mitteilungen aus dem Zoologischen Museum Hamburg. Bd.12. No.158. S.309-316.

Lourenço W.R. 1999a. A new species of Cicileus Vachon, 1948 (Chelicerata, Scorpiones, Buthidae) from Niger // Entomologische Mitteilungen aus dem Zoologischen Museum Hamburg. Bd.13. No.159. S.29-36.

Lourenço W.R. 1999b. Un nouveau genre et une nouvelle espèce de scorpion d'Egypte, appartenant à la famille des Buthidae Simon // Revue suisse de Zoologie. T.106. Fasc.3. P.591-598. 
Lourenço W.R. 2001. Un nouveau genre et une nouvelle espèce de scorpion d'Algérie, avec des considérations taxonomiques sur le genre Lissothus Vachon, 1948 (Scorpiones, Buthidae) // Zoosystema. T.23. Fasc.1. P.51-57.

Lourenço W.R. 2002. Considérations sur les modèles de distribution et différentiation du genre Buthus Leach, 1815, avec la description d'une nouvelle espèce des montagnes du Tassili des Ajjer, Algérie (Scorpiones, Buthidae) // Biogeographica. T.78. Fasc.3. P.109-127.

Lourenço W.R. 2003. Compléments à la faune de scorpions (Arachnida) de l'Afrique du Nord, avec des considérations sur le genre Buthus Leach, 1815 // Revue suisse de Zoologie. T.110. Fasc.4. P.875-912.

Lourenço W.R. 2004. On the genus Hottentota Birula 1908, with the description of a new species from Chad (Scorpiones, Buthidae) // Entomologische Mitteilungen aus dem Zoologischen Museum Hamburg. Bd.14. No.170. S.211-218.

Lourenço W.R. 2005. Nouvelles considérations taxonomiques sur les espèces du genre Androctonus Ehrenberg, 1828 et description de deux nouvelles espèces (Scorpiones, Buthidae) // Revue suisse de Zoologie. T.112. Fasc.1. P.145-171.

Lourenço W.R. 2006. Further considerations on the genus Buthacus Birula, 1908 (Scorpiones, Buthidae), with a description of one new species and two new subspecies // Boletin de la Sociedad Entomológica Aragonesa. T.38. P.59-70.

Lourenço W.R. 2009. Reanalysis of the genus Scorpio Linnaeus 1758 in sub-Saharan Africa and description of one new species from Cameroon (Scorpiones, Scorpionidae) // Entomologische Mitteilungen aus dem Zoologischen Museum Hamburg. Bd.15. No.181. S.99-113

Lourenço W.R. 2010a. The Compsobuthus species from 'Tassili des Ajjer', Algeria (Scorpiones, Buthidae) and description of a new species // Entomologische Mitteilungen aus dem Zoologischen Museum Hamburg. Bd.15. No.182. S.147-155.

Lourenço W.R. 2010b. A new species of Butheoloides Hirst, 1925 from Morocco (Scorpiones, Buthidae) // Entomologische Mitteilungen aus dem Zoologischen Museum Hamburg. Bd.15. No.183. S.183-189.

Lourenço W.R., Cloudsley-Thompson J.L. 2009. A new species of the genus Scorpio Linnaeus 1758 from Sudan (Scorpiones, Scorpionidae) // Boletin de la Sociedad Entomologica Aragonesa. T.45. P.123-126.

Lourenço W.R., Duhem B. 2007. Observations on the remarkable disrupted geographical distribution of the genus Microbuthus Kraepelin, 1898 in North Africa, with the description of a new species from Egypt (Scorpiones, Buthidae) // Comptes Rendus Biologies. T.330. Fasc.5. P.439-445.

Lourenço W.R., Duhem B., Cloudsley-Thompson J.L. 2010. A new relictual buthid scorpion from the region of the Great Rift Valley in Kenya (Scorpiones, Buthidae) // Comptes Rendus Biologies. T.333. Fasc.3. P.280-285.

Lourenço W.R., Leguin E.-A. 2011. Further considerations on the species of the genus Orthochirus Karsch, 1891 from Africa, with description of three new species (Scorpiones: Buthidae) // Euscorpius. No.116. P.1-19.

Lourenço W.R., Sun D., Zhu M.-S. 2009. About some Compsobuthus Vachon, 1949 from Africa and the Middle East with the description of a new species (Scorpiones, Buthidae) // Boletin de la Sociedad Entomológica Aragonesa. T.45. P.53-58.

Lourenço W.R., Vachon M. 2004. Considérations sur le genre Buthus Leach, 1815 en Espagne, et description de deux nouv- elles espèces (Scorpiones, Buthidae) // Revista Ibérica de Aracnologia. T.9. P.81-94.

Lowe G. 2010. New picobuthoid scorpions (Scorpiones: Buthidae) from Oman // Euscorpius. No.93. P.1-53.

Pellegrin J. 1935. Scorpions. Mission au Tibesti // Mémoires de l'Académie des Sciences. T.62. P.53.

Polis G .A. 1990. Ecology // Polis G.A. (Ed.), The Biology of Scorpions. Stanford: Stanford University Press. P.247-293.

Qi J.-X., Lourenço, W. R. 2007. Distribution of endemic relict groups of Saharan scorpions, with the description of new genus and species from Mauritania // Comptes Rendus Biologies. T.330. Fasc.1. P.80-85.

Schuster M., Duringer P., Ghienne, J.-F., Vignaud P., Mackaye H.T., Likius A., Brunet M. 2006. The age of the Sahara Desert // Science. Vol.311. No.5762. P.821.

Stahnke H.L. 1970. Scorpion nomenclature and mensuration // Entomological News. Vol.81. No.12. P.297-316.

Vachon M. 1940. Voyage en A.O.F. de L. Berland et J. Millot. Scorpions. V // Bulletin de la Société zoologique de France. T.65. P.170-184.

Vachon M. 1950. Contribution à l'étude de l'Aïr (Mission L. Chopard et A. Villiers) - Scorpions, Pseudoscorpions et Solifuges // Mémoires de l'Institut français de Afrique noire. T.1. P.93-107.

Vachon M. 1951. Biogéographie des Scorpions du Nord de 1'Afrique // Compte Rendus Sommaires des Séances de la Société de Biogéographie. T.241. P.61-65.

Vachon M. 1952. Etudes sur les scorpions. Publications de l'Institut Pasteur d'Algérie. 482 pp.

Vachon M. 1953. Contribution à l'étude du peuplement de la Mauritanie. Scorpions // Bulletin de l'Institut français d'Afrique noire. T.15. Fasc.3. P.1012-1028.

Vachon M. 1958. Scorpions, Mission scientifique au Tassili des Ajjer (1949) // Travaux de l'Institut de recherches sahariennes de 1'Université d'Alger. Zoologie pure et appliqué. T.3. P.177193.

Vachon M. 1963. De l'utilité, en systématique, d'une nomenclature des dents des chélicères chez les Scorpions // Bulletin du Muséum national d'Histoire naturelle, Paris. Sér. 2. No.35, Fasc.2. P.161-166.

Vachon M. 1974. Etude des caractères utilisés pour classer les familles et les genres de Scorpions (Arachnides). 1. La trichobothriotaxie en arachnologie. Sigles trichobothriaux et types de trichobothriotaxie chez les Scorpions // Bulletin du Muséum national d'Histoire naturelle, Sér.3. No.140, Zool. No.104. P.857-958.

Vachon M. 1975. Sur l'utilisation de la trichobothriotaxie du bras des pédipalpes des Scorpions (Arachnides) dans le classement des genres de la famille des Buthidae Simon // Comptes Rendus des Séances de l'Académie des Sciences, Paris. T.281. No.4. P.1597-1599.

White F. 1983. The vegetation of Africa, a descriptive memoir to accompany the UNESCO/AETFAT/UNSO Vegetation Map of Africa // (3 Plates, Northwestern Africa, Northeastern Africa, and Southern Africa, 1:5000.000). UNESCO, Paris.

Wickens G.E. 1976. The flora of the Jebel Marra (Sudan Republic) and its geographical affinities // Kew Bulletin, Additional Series. Vol.5. P.1-368.

Responsible editor S.I. Golovatch 